\title{
A novel mouse model expressing human forms for complement receptors CR1 and CR2
}

\author{
Harriet M. Jackson ${ }^{1,2}$, Kate E. Foley ${ }^{1,3}$, Rita O'Rourke ${ }^{1}$, Timothy M. Stearns ${ }^{1}$, Dina Fathalla ${ }^{2}$, B. Paul Morgan ${ }^{2}$ and
} Gareth R. Howell ${ }^{1,3,4^{*}}$ (D)

\begin{abstract}
Background: The complement cascade is increasingly implicated in development of a variety of diseases with strong immune contributions such as Alzheimer's disease and Systemic Lupus Erythematosus. Mouse models have been used to determine function of central components of the complement cascade such as C1q and C3. However, species differences in their gene structures mean that mice do not adequately replicate human complement regulators, including $C R 1$ and $C R 2$. Genetic variation in $C R 1$ and $C R 2$ have been implicated in modifying disease states but the mechanisms are not known.
\end{abstract}

Results: To decipher the roles of human CR1 and CR2 in health and disease, we engineered C57BL/6J (B6) mice to replace endogenous murine $\mathrm{Cr} 2$ with human complement receptors, CR1 and CR2 (B6.CR2CR1). CR1 has an array of allotypes in human populations and using traditional recombination methods ( $F / p$-frt and $(\mathrm{Cre}-$ loxP) two of the most common alleles (referred to here as $C R 1^{\text {long }}$ and $C R 1^{\text {short }}$ ) can be replicated within this mouse model, along with a $C R 1$ knockout allele $\left(C R 1^{K O}\right)$. Transcriptional profiling of spleens and brains identified genes and pathways differentially expressed between mice homozygous for either $C R 1^{\text {long }}, C R 1^{\text {short }}$ or $C R 1^{K O}$. Gene set enrichment analysis predicts hematopoietic cell number and cell infiltration are modulated by $C R 1^{\text {iong }}$, but not $C R 1^{\text {short }}$ or $C R 1^{K O}$. Conclusion: The B6.CR2CR1 mouse model provides a novel tool for determining the relationship between humanrelevant $C R 1$ alleles and disease.

Keywords: Complement cascade, Complement regulators, Immune cells, Alzheimer's disease, Lupus, Hematopoietic cells, Immune cell infiltration

\section{Background}

The complement cascade is an integral component of our innate immune response and a first line of defense against bacterial infections. Various components of the complement cascade are constantly surveying for invading pathogens or debris, and tagging them for destruction. This system is composed of a number of plasma

\footnotetext{
* Correspondence: gareth.howell@jax.org

'The Jackson Laboratory, 600 Main Street, Bar Harbor, ME, USA

${ }^{3}$ Graduate School of Biomedical Sciences, Tufts University School of Medicine, Boston, MA, USA

Full list of author information is available at the end of the article
}

and membrane bound proteins and is tightly regulated. Circulating complement components are produced in the liver but can also be produced by specific cells in tissues.

In recent years, the recognized roles of the complement cascade have expanded. For example, the complement cascade is integral for the process of synapse pruning during development and disease [68, 70], for regulation of embryo survival $[46,84]$, and for tissue regeneration $[19,49,66]$. Many of these novel roles were

(c) The Author(s). 2020 Open Access This article is licensed under a Creative Commons Attribution 4.0 International License, which permits use, sharing, adaptation, distribution and reproduction in any medium or format, as long as you give appropriate credit to the original author(s) and the source, provide a link to the Creative Commons licence, and indicate if changes were made. The images or other third party material in this article are included in the article's Creative Commons licence, unless indicated otherwise in a credit line to the material. If material is not included in the article's Creative Commons licence and your intended use is not permitted by statutory regulation or exceeds the permitted use, you will need to obtain permission directly from the copyright holder. To view a copy of this licence, visit http://creativecommons.org/licenses/by/4.0/ The Creative Commons Public Domain Dedication waiver (http://creativecommons.org/publicdomain/zero/1.0/) applies to the data made available in this article, unless otherwise stated in a credit line to the data. 
initially identified from animal models before being validated in human studies.

While animal models have proven fruitful in delivering greater understanding of the central components of the complement cascade such as $\mathrm{Clq}$ and C3, there are current limitations in studying human complement regulation in mice. In humans, the complement cascade is regulated in part by a series of genes on human chromosome 1 within the Regulators of Complement Activation (RCA) cluster [30, 42, 43, $63,64,76]$. A major difference in the RCA cluster between humans and mice is in the locus encoding Complement Receptor 1 (CR1/CD35), that is absent in mice $[25,33,54]$. CR1 is both a receptor and a negative regulator of the complement cascade, binding to $\mathrm{C} 3 \mathrm{~b}, \mathrm{C} 4 \mathrm{~b}, \mathrm{C} 1 \mathrm{q}$, and $\mathrm{MBL}$ proteins. The interactions with $\mathrm{C} 3 \mathrm{~b}$ and $\mathrm{C} 4 \mathrm{~b}$ are considered to be the major function of this receptor [32, 39, 40, 80, 85].

Genetic variation in CR1 has been associated with a variety of diseases, such as Alzheimer's disease [3, 8, 9, 12, 27, 34, 36, 41, 72], Malaria [4, 37, 71, 83], and Systemic Lupus Erythematous [5, 13, 29, 35, 37, 48, 52, 53, $60,65,75,78,82]$; however, in many cases the precise genetic variations have not been identified. CR1 has at least four allotypes: CR1-F, CR1-S, CR1-F' and CR1-D (also known as CR1-A, CR1-B, CR1-C and CR1-D respectively) [20-23, 73]. These four allotypes differ in size through presence or absence of long homologous repeats (LHRs; each comprising seven short consensus repeats [SCRs]); the commonest form, CR1-F (gene frequency 0.87 in Caucasians), comprises four LHR and a total of 30 SCRs while the CR1-S allotype (gene frequency 0.11) comprises five LHRs and a total of 37 SCRs $[28,80]$. Some studies suggest different allotypes may be responsible for modifying risk for disease but currently there is no effective model system in which to test this $[2,3,7,27]$. To address this knowledge gap, we created a novel mouse model that enables the expression of different forms of human CR1 that we refer to as $C R 1^{\text {long }}$ (equivalent to CR1-S) and $C R 1^{\text {short }}$ (equivalent to CR1-F) (Fig. 1). Previous mouse models have relied on either the mouse $\mathrm{Cr} 2$ or Crry genes or on transgenically expressed forms of CR1 to study the function of human CR1 in mice $[18,38,44,45,47,55,57-59,81]$. For instance, in the model created by Pappworth et al., human forms of $C R 1$ and $C R 2$ were expressed in mice using a transgenic approach and functional assessments made in a mouse Cr2-deficient background [55]. In the model we now present here, CR1 is expressed within the equivalent region of the mouse genome with human relevant promoter and regulatory sequences in conjunction with the expression of human CR2 driven by the mouse $\mathrm{Cr} 2$ promoter. Transcriptional profiling of the spleen and brain reveals significant differences in gene expression between mice carrying different allotypes of CR1 supporting the use of this new mouse model as a tool for studying CR1-dependent disease mechanisms.

\section{Results}

Chimeras produce viable, construct-carrying pups with successful Germline transmission

To overcome species differences between mice and humans, we developed a new mouse model that, in the place of mouse $\mathrm{Cr} 2(\mathrm{mCr} 2)$, expresses human $C R 2$ and CR1 (Figs. 1a-b and 2, see Methods). The B6.CR2CR1 mouse model is capable of expressing two isoforms of CR1 (CRI long and CR1 ${ }^{\text {short }}$, Figs. 1b) representing common allotypes predicted to be relevant to human disease $[2,3,27]$. The difference between $C R 1^{\text {long }}$ and $C R 1^{\text {short }}$ is the number of LHR regions (Figs. 1c). To maximize relevance to human $C R 1$ regulation, we have incorporated the human intergenic region (HIR) between the CR2 and $C R 1$ genes (Fig. 2). To create the B6.CR2CR1 strain, B6 ES cells were targeted with a synthetic construct using recombineering (Fig. 2a, see methods). Twenty-eight chimeras, derived from two chimeric lines $(5 \mathrm{H} 4$ and 5E2, Fig. 2b), were assayed for the presence of the construct. Chimeric mice carrying the synthetic construct were bred to $\mathrm{B}^{\mathrm{Tyr}}$, and all black progeny were genotyped to confirm transmission (Fig. 2c). No sex bias was seen with regards to transmission of the construct. Once germline transmission, and no sex bias, was confirmed the development of the CR1 allelic series $\left(C R 1^{\text {long }}\right.$, $C R 1^{\text {short }}, C R 1^{K O}$ ) was performed (Fig. 2c). All genotypes developed through the allelic series were successfully bred to homozygosity through brother/sister matings. Allele-specific genotyping was used to determine the presence or absence of specific regions that defined each strain (mCr2, CR2, CR1 $1^{\text {long }}, C R 1^{\text {short }}, C R 1^{K O}$, HIR; Fig. 3, see methods). Of note, the initial establishment of the B6.CR2CR1 $1^{K O / K O}$ line proved difficult, as low numbers of homozygous mice were generated. However, once a male and female B6.CR2CR1 $1^{K O / K O}$ were identified, a mating pair was established, and the litter sizes were comparable to those of the other strains.

\section{RNA and protein expression of $C R 1$ and $C R 2$ in spleens of B6.CR2CR1 mice}

To establish RNA and protein expression of $C R 1$ and $C R 2$, splenic tissue was assessed. As a primary organ of murine $\mathrm{Cr} 2$ expression and complement-dependent immune complex processing, the spleen was an ideal target to validate the expression of human $C R 1$ and $C R 2$. cDNA was generated from whole spleens of 3 males and 3 females from each genotype. Targeted primers confirmed the presence of human $C R 2$ and $C R 1$ in the spleen and the absence of mouse $\mathrm{Cr} 2$ (Fig. 4a-e). For 


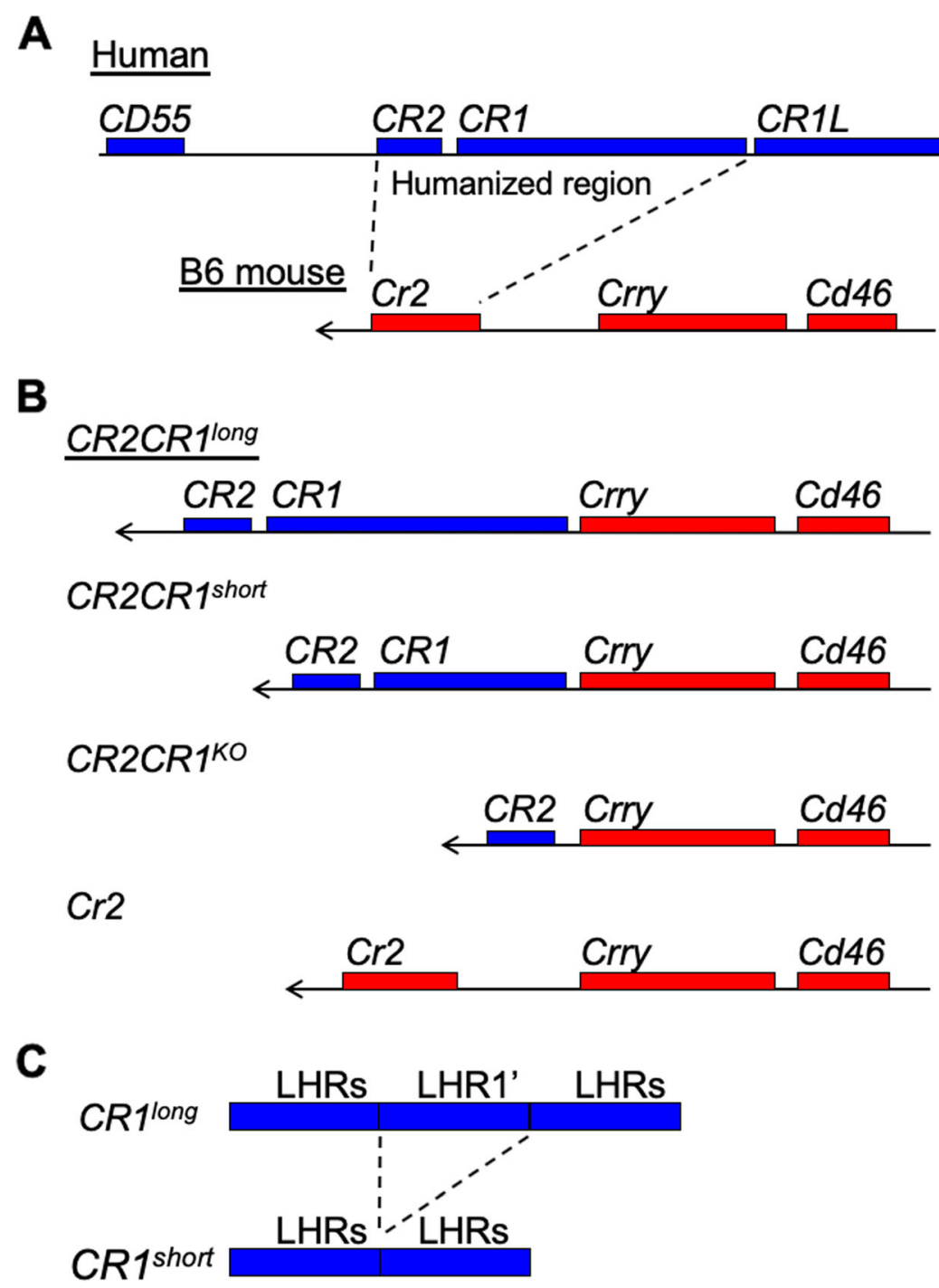

Fig. 1 The B6.CR2CR1 strain incorporates human CR2 and common isoforms of human CR1 into the mouse RCA cluster. a Humans and B6 mice differ in the genes they contain within the regulation of complement activation (RCA cluster). Human genes (blue boxes) include CR2, CR1 and CR1L whereas B6 mouse genes (red boxes) include Cr2 and Crry. b-c The B6.CR2CR1 strain contains the human CR2 gene and a long form of the human CR1 gene (containing multiple Long Homologous Repeats, LHR). Through recombination using the Flp/FRT system, one LHR (LHR') can be removed from the $C R 1$ gene. Through recombination using the Cre/LoxP system, the majority of the human CR1 gene can be deleted

CR1, primers designed for CR1 targeted both exon 2 and a region spanning exons 4 and 5 . This strategy enabled identification of $\mathrm{B} 6 . C R 2 C R 1^{K O / K O}$ mice that produced a transcript containing only the first two exons but not exons 4 and 5 . As expected, Crry transcript, a mousespecific gene that lies downstream of $\mathrm{Cr} 2$, was seen in all samples (Fig. 4e).

To evaluate expression of human CR1 and CR2 protein isoforms, first, western blotting using an anti-CR1 antibody was performed on spleen samples from B6.CR2CR1 $1^{\text {long/long }}, \mathrm{B} 6 . C R 2 C R 1^{\text {short/short }}$ and B6 mice. An approximately $250 \mathrm{kDa}$ band was detected in B6.CR2CR1 $1^{\text {long/long }}$ mice, while an approximately 225 $\mathrm{kDa}$ band was detected in B6.CR2CR1 $1^{\text {short short }}$ mice
(Figs. 4f and S1). These data agree with the predicted sizes based on the amino acid sequences for CR $1^{\text {long }}$ (273 kDa, 2494 amino acids) and CR1 $1^{\text {short }}(223 \mathrm{kDa}$, 2044 amino acids) (see Supplement File 1). CR1 protein expression appeared greater B6.CR2CR $1^{\text {short/short }}$ compared to B6.CR2CR1 $1^{\text {long } / \text { long }}$ mice. No band was present at either of these sizes in B6 control mice. To quantify $\mathrm{CR} 1$ and $\mathrm{CR} 2$ protein expression in the spleen, western blots were performed on B6.CR2CR1 long/long, B6.CR2CR1 $1^{\text {short/short }}, \mathrm{B} 6 . C R 2 C R 1^{K O / K O}$ and $\mathrm{B} 6$ mice (Figs. 5a-c and S2). Samples from B6.CR2CR1 long/long mice showed significantly lower levels of CR1 protein expression compared to samples from B6.CR2CR $1^{\text {short/ }}$ ${ }^{\text {short }}$ mice (Fig. 5b-c). 


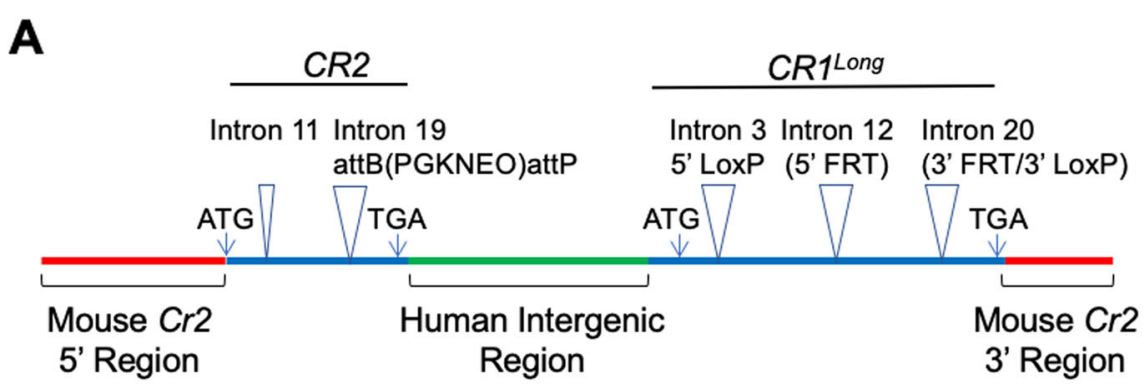

B

Chimeras
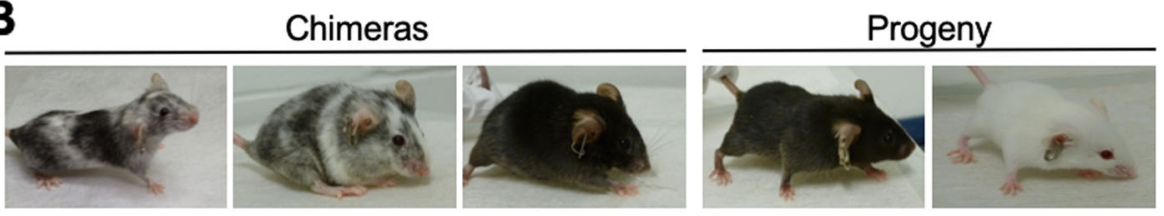

C

Chimera

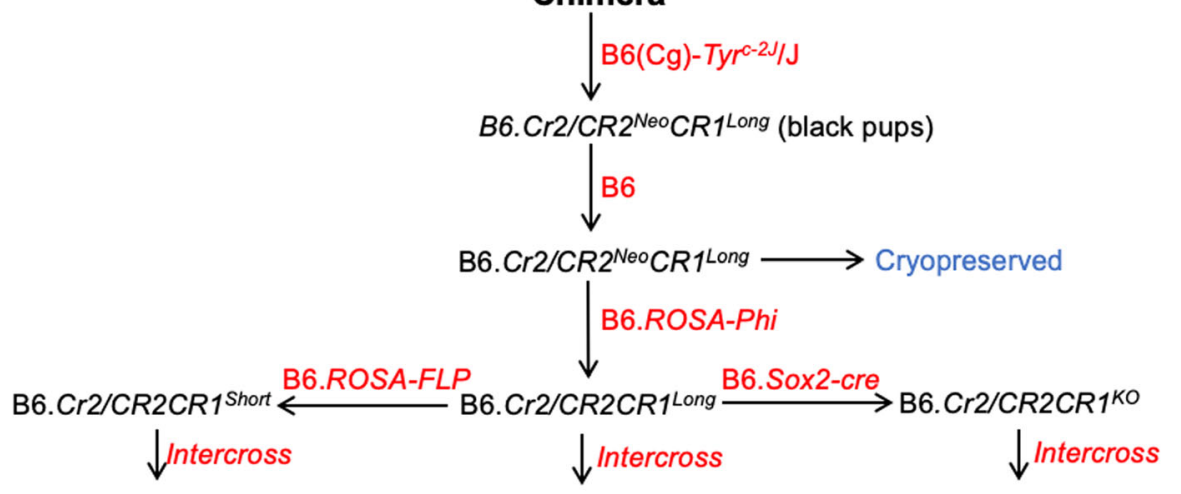

B6.CR2CR1 1 Shortshort

B6.CR2CR1Long/Long

B6.CR2CR1Kо/KO

Fig. 2 Creation of the B6.CR2CR1 mouse strain. a The synthetic construct inserted into the B6 mouse genome (red bars) at the $\mathrm{Cr} 2$ locus encompasses both the human $C R 2$ and $C R 1$ genes (blue bars), and included the human intergenic region between CR2 and CR1 (green bar). Human CR2 sequence was based on NCBI reference sequence NM_001006658. Two introns (equivalent to introns 11 and 19) were included in human CR2 gene. Intron 19 contained a neomycin cassette (PGKNEO) flanked by AttB and AttP sites. Human CR1 sequence was based on NCBI reference sequence NM_000651. Three introns (equivalent to introns 3, 12 and 20) were included in the human CR1 gene. LoxP sites were added to introns 3 and 20, FRT sites were added to introns 12 and 20. See Supplemental File CR1 and CR2 protein alignments for comparison of CR1 long, $\mathrm{CR} 1^{\text {short }}$ and CR2 protein sequences to reference protein sequence. $\mathbf{b}$ Example images of chimeras and progeny from the $5 \mathrm{H} 4 \mathrm{ES}$ cell line. Black pups were genotyped for the presence of the synthetic construct and used to establish subsequent strains. $\mathbf{c}$ The breeding schemes to generate strains and experimental cohorts

Mice of all genotypes showed a band of similar intensity at $\sim 148 \mathrm{kDa}$ - the expected size of the orthologous CR2 isoform in humans and mice (Figs. 5d-f Fig. S2). In addition, a second $\sim 190 \mathrm{kDa}$ band was observed that we expect to be the second CR2 isoform known to be expressed in mice. The $148 \mathrm{kDa}$ band showed greatest expression in B6 mice, but very low levels of expression in some mice expressing human forms of CR2. This may be due to the fact that the human CR2 transcript expression is driven from the mouse $\mathrm{Cr} 2$ promoter, and includes the mouse $\mathrm{Cr} 25^{\prime}$ UTR. Therefore, we cannot rule out a small amount of alternatively spliced human
CR2 in the B6.CR2CR1 mice. A third band, a little smaller than $148 \mathrm{kDa}$, was only observed in $\mathrm{B} 6$ mice but not B6.CR2CR1 mice and may indicate an as yet uncharacterized CR2 isoform.

CR ${ }^{\text {long }}$ modifies expression of more genes in the brain and spleen compared to $C R 1^{\text {short }}$

Transcriptional profiling was performed to identify transcriptional differences between B6.CR2CR1 and B6 mice. Spleen and brain samples from three male and three female B6.CR2CR1 $1^{\text {long/long, }}, \mathrm{B} 6 . C R 2 C R 1^{\text {short/short }}$, B6.CR2CR1 $1^{K O / K O}$ and B6 controls were assessed (24 


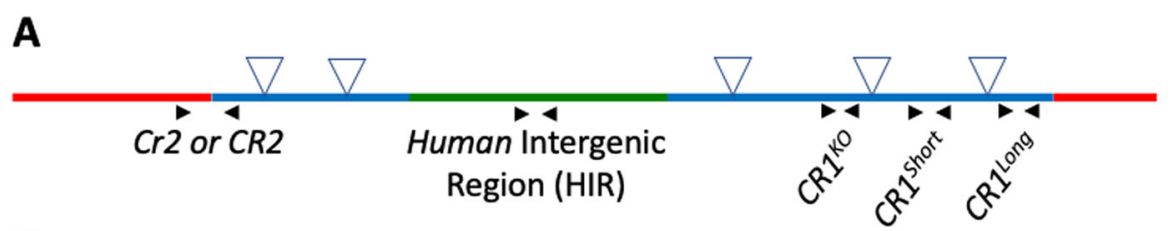

B
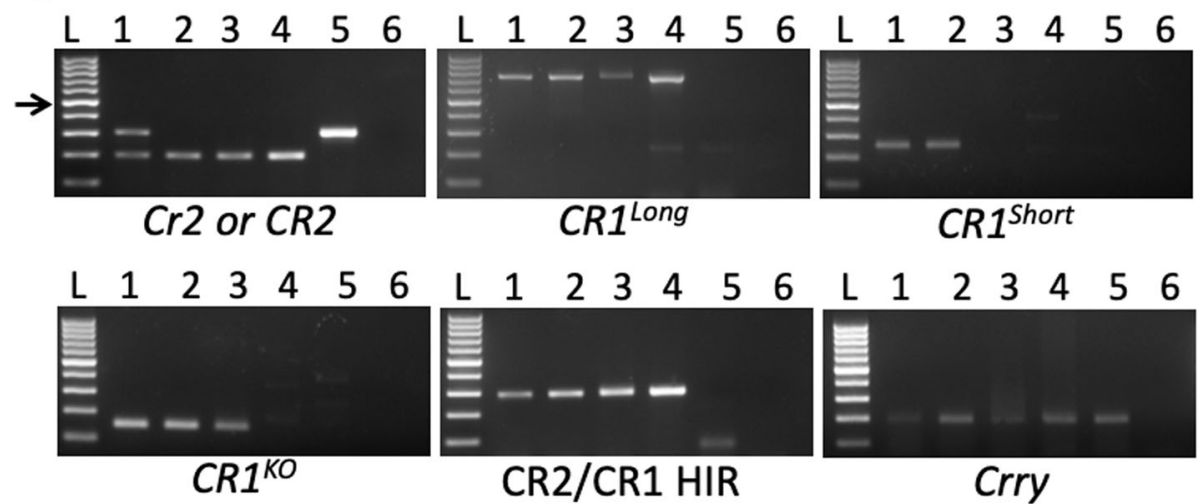

Fig. 3 Validation of genomic regions within the B6.CR2CR1 strains. a Location of primer pairs (black arrows) used to validate genomic regions. $\mathbf{b}$ The presence and absence of bands confirmed the presence or absence of each of the genomic regions and confirmed the Crry gene has not been disrupted. Mouse $C r 2=300$ bp product. Human $C R 2=198$ bp product. $C R 1^{\text {long }}=\sim 800$ bp product. $C R 7^{\text {short }}$ (deletion between intron 12 and intron 20) $=$ no product. $C R 7^{K O}$ (deletion between intron 3 to intron 20, Fig. 2a) $=$ no product. $C R 2 C R 1$ Human Intergenic Region $(H I R)=291$ bp product. Crry $=190 \mathrm{bp}$ product. L - Ladder (100 bp ladder, arrow is $500 \mathrm{bp}$ ). 1 - heterozygous B6.CR2CR 1ong/+ with Neomycin cassette. 2 -

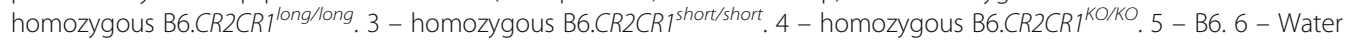

samples in total). There were no differences between male vs female for each of the three comparisons, so samples were pooled by genotype to increase the quantity from three (three per sex) to six (pooled sexes). First, the spleen samples were analyzed (Fig. 6a-c). Compared to $\mathrm{B} 6$ controls, B6.CR2CR1 $1^{\text {long } / \text { long }}$ mice showed a greater number of differentially expressed (DE) genes than B6.CR2CR1 $1^{\text {short/short }}$ mice (104 and 38 genes respectively, Tables S1 and S2). Only ten genes were DE when comparing B6.CR2CR1 ${ }^{K O / K O}$ mice to $\mathrm{B} 6$ (Table S3) suggesting that, at least in the spleens of young, healthy mice, the human $C R 2$ gene functions similarly to mouse $\mathrm{Cr} 2$. Interestingly, the expression of the $C R 1^{\text {short }}$ transcript was almost twice as high as the $C R 1^{\text {long }}$ transcript (9.4 counts per million $(\mathrm{cpm})$ compared to $5.6 \mathrm{cpm}$ respectively) supporting our previous data that showed a greater amount of $\mathrm{CR} 11^{\text {short }}$ protein in comparison to CR $1^{\text {long }}$ protein (Figs. 4f, 5, S1 and S2).

To predict functional relevance of the $104 \mathrm{DE}$ genes comparing spleen samples from B6.CR2CR1 $1^{\text {long/long }}$ compared to B6, Kyoto Encyclopedia of Genes and Genomes (KEGG) and Gene Ontology (GO) term enrichment analyses were performed. Four KEGG pathways were significantly enriched $(p<0.05)$, with two of the four relevant to amylase related genes (starch and sucrose metabolism, carbohydrate digestion and absorption) and the other two pathways (African trypanosomiasis and malaria) driven by 'heme' related genes. Enriched biological processes included metabolic terms such as 'cellular oxidant detoxification' and 'carbohydrate catabolic process'. Interestingly, 'negative regulation of histone acetylation' was significant, suggesting that expression of CR1 in B6.CR2CR1 $1^{\text {long/long }}$ mice may affect some epigenetic signatures when compared to B6 controls. For molecular function (MF), GO terms showed changes relating to binding, such as 'haptoglobin binding', 'chloride ion binding', 'organic acid binding' and 'copper ion binding', indicating that the $C R 1^{\text {long }}$ gene may be playing a role in intracellular binding (Fig. 6c). None of these pathways or GO terms were enriched in the DE genes comparing samples from B6.CR2CR1 $1^{\text {short/short }}$ mice or B6.CR2CR1 $1^{K O / K O}$ to $\mathrm{B} 6$.

The number of DE genes was greater in the brain when compared to the spleen (Fig. 6d). There were $183 \mathrm{DE}$ genes identified by comparing B6.CR2CR1 $1^{\text {longllong }}$ mice to $\mathrm{B} 6$ (Table S4), $58 \mathrm{DE}$ when comparing B6.CR2CR1 $1^{\text {shortshort }}$ with B6 (Table $\mathrm{S} 5)$, and only $5 \mathrm{DE}$ genes between $\mathrm{B} 6 . \mathrm{CR} 2 \mathrm{CR} 1^{\mathrm{KO} / K O}$ and B6 (Table S6). This trend reflects the results seen in the spleen, indicating that expression of $C R 1^{\text {long }}$ in mice had the greatest effect on gene expression in the brain compared with mice expressing either $C R 1^{\text {short }}$ or $C R 1^{K O}$. The $C R 1^{\text {long }}$ transcript was expressed at a much lower levels in the brain $(0.5 \mathrm{cpm}$ on average $)$ 


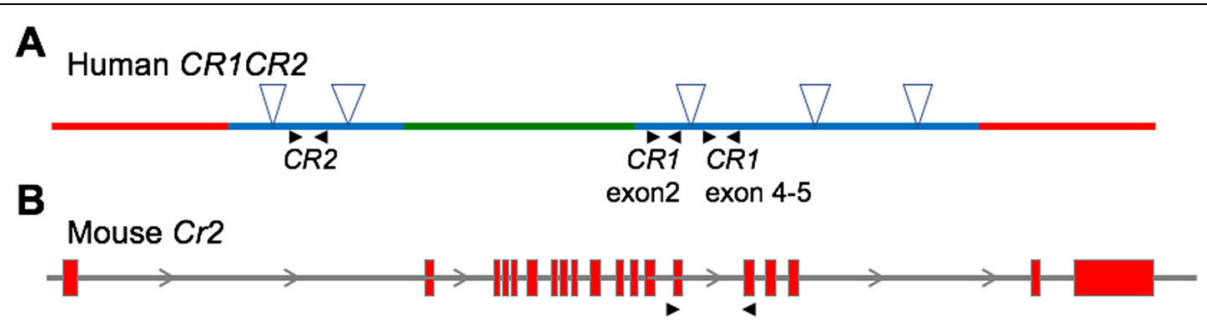

C

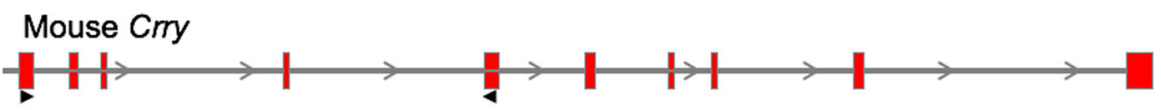

D

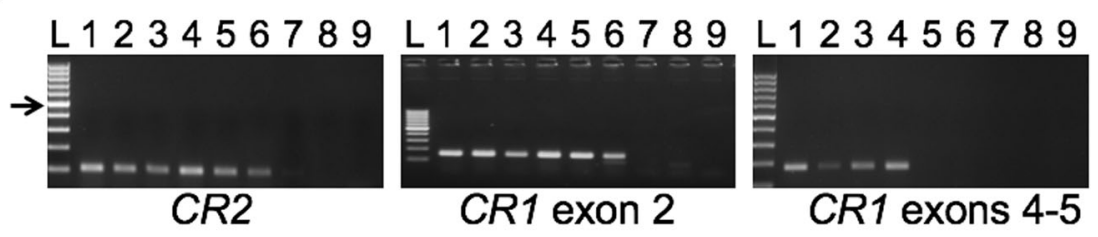

E
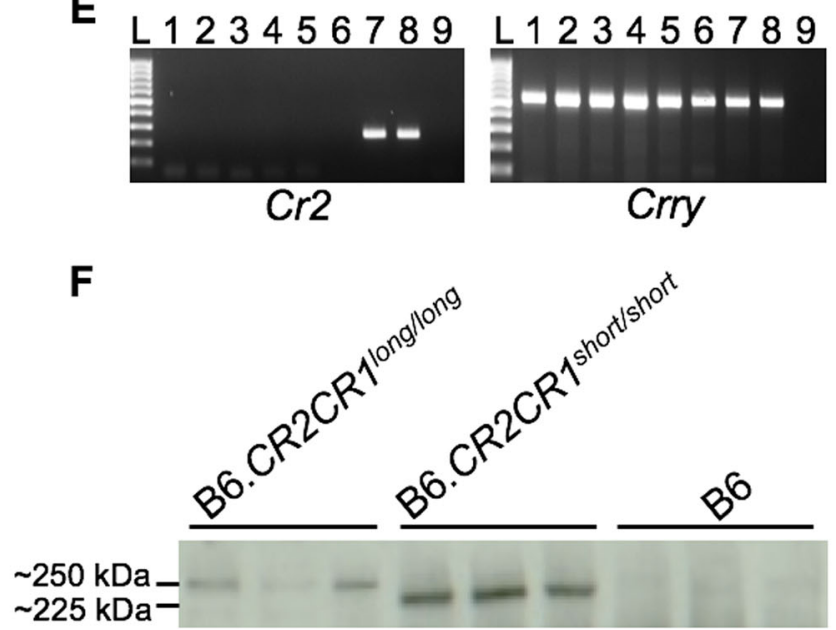

Fig. 4 Generation of transcript and protein from the humanized region of the B6.CR2CR1 mice. a-c Each graphic depicts the humanized CR2CR1 region (a), mouse $\mathrm{Cr} 2$ gene $(\mathbf{b})$ and mouse Crry gene (c). Black arrows denote the location of primer pair. $\mathbf{d}$ All B6.CR2CR1 mice show expression of human CR2 and CR1 (exon 2). Only B6.CR2CR1 1ong/long and B6.CR2CR1 $1^{\text {short/short }}$ show expression of CR1 exons 4-5. e Only B6 mice show mouse Cr2 expression. All mice show expression of mouse Crry. L- Ladder (100 bp ladder, arrow is 500 bp). 1 - Female B6.CR2CR 1ong/long . 2 - Male

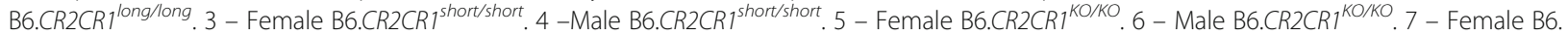
8 - Male B6. 9 - Water. Product sizes for RT-PCR are provided in the methods. $\mathbf{f}$ Western blot indicating B6.CR2CR1 mice produce protein products at their expected molecular weight. B6.CR2CR1 long/long mice produce a product larger than that of their B6.CR2CR1 $1^{\text {short/short }}$ counterparts. No

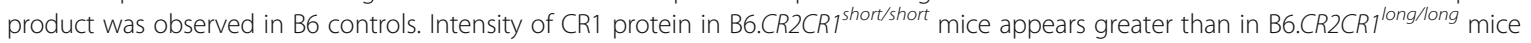

compared to the spleen, while no $C R 1^{\text {short }}$ transcripts were detected in the brain.

To identify the biological relevance of the 183 genes $\mathrm{DE}$ in brains of B6.CR2CR1 long/long compared to B6, KEGG and GO term gene set enrichment was performed. Only one KEGG pathway, 'Fanconi anemia pathway' was significant $(p<0.05)$ in the $\mathrm{DE}$ gene set between B6.CR2CR $1^{\text {long/long }}$ and B6 controls. Enrichment of this pathway was driven by the genes ' $W d r 48$ ', 'Atr', and 'Rev1' which respond to DNA damage. GO BP terms associated with differences between B6.CR2CR1 long/long and B6 controls identified 'regulation of transcription, DNA-templated', 'phosphorylation', and 'cellular response to DNA damage stimulus' indicating DNAdamage response genes may be affected by the $C R 1^{\text {long }}$. GO MF analysis identified terms involved in kinase activity and DNA binding, further suggesting potential involvement in DNA repair mechanisms. No pathways or GO terms were enriched in mice expressing either $C R 1^{\text {short }}$ or $C R 1^{K O}$ (compared to B6) further supporting 

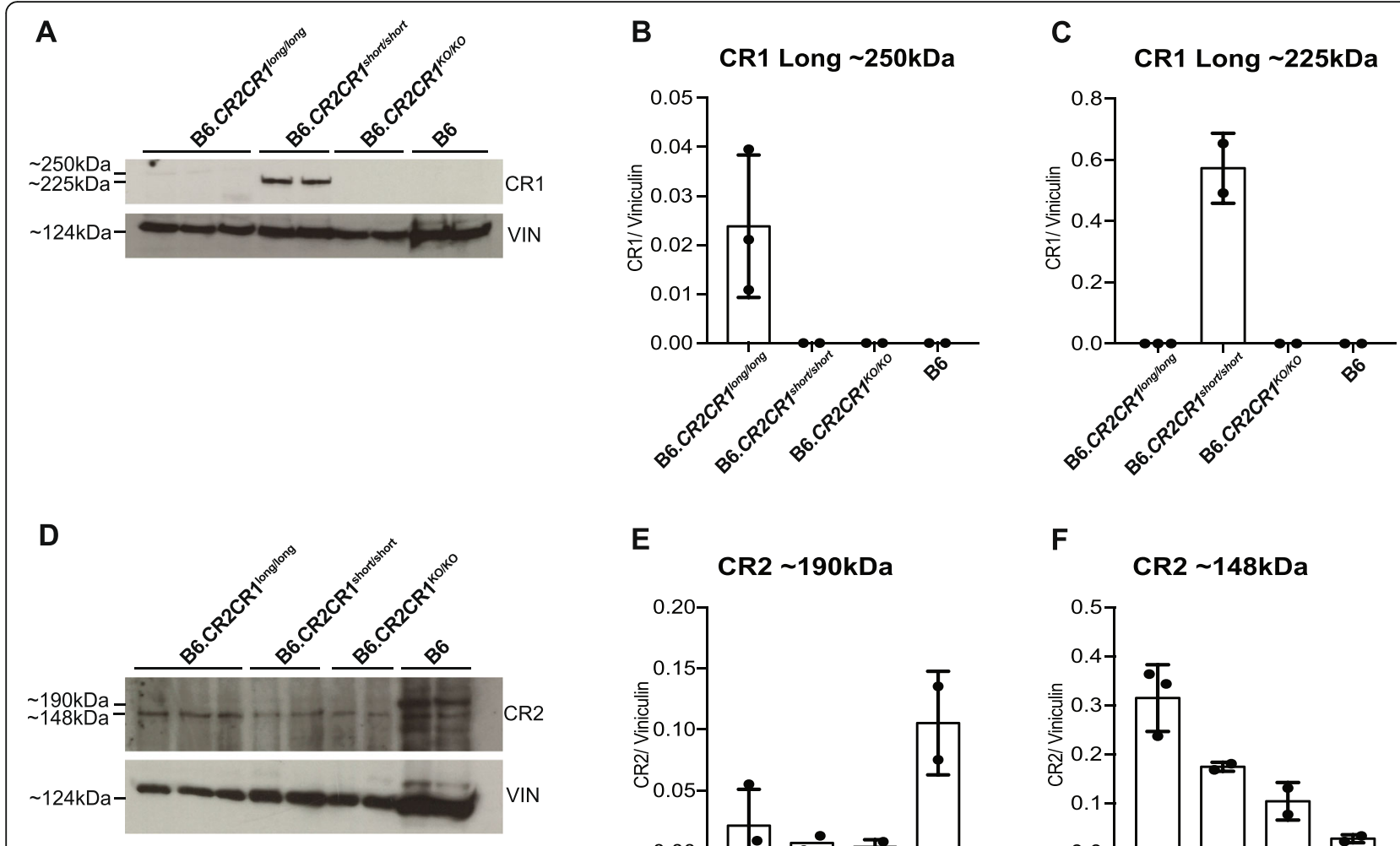

E

CR2 190kDa

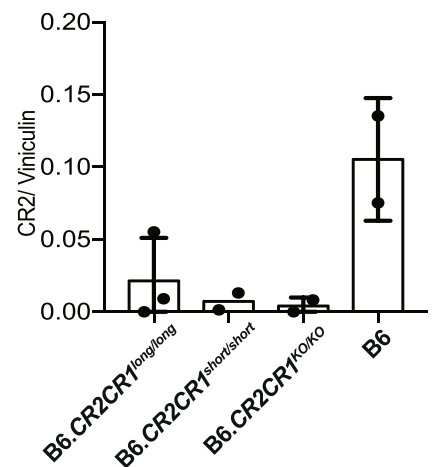

$\mathbf{F}$

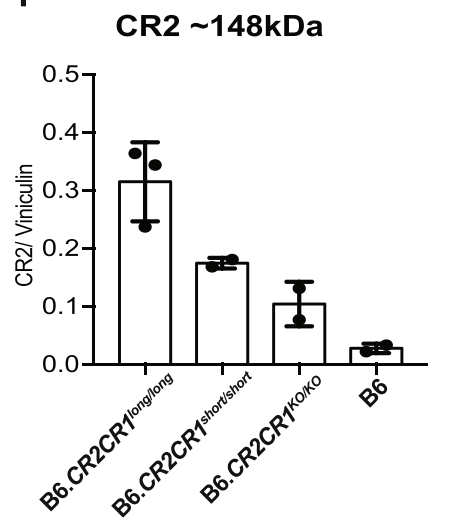

Fig. 5 Evaluating CR1 and CR2 protein expression in the spleens of CR2CR1 mice. a-c Western blot using anti-CD35/CR1 indicating presence of an approximately $250 \mathrm{kDa}$ band in B6.CR2CR long/long mice but an approximately $250 \mathrm{kDa}$ band in B6.CR2CR1 $1^{\text {short/short }}$ mice. No bands of these sizes were detected in either $B 6 . C R 2 C R 1^{K O / K O}$ or $B 6$ mice. Comparing the $C R 1^{\text {long. }}$ :vinculin ratio with $C R 1^{\text {short }}$ :vinculin ratio it is clear that $C R 1^{\text {short }}$ is $\mathrm{more}$ highly expressed in the spleen than CR1 ${ }^{\text {long }}$. $\mathbf{d}$-f Western blot using anti-CD21/CR2 indicating presence of a $148 \mathrm{kDa}$ band in all samples and a $190 \mathrm{kDa}$ band strongly expressed in B6 mice - likely representing the alternative spliced product previously identified in mice. A very faint band appears in some B6.CR2CR1 samples. An additional previously uncharacterized band, smaller than $148 \mathrm{kDa}$, is also observed in B6 mice. Loading control $=$ Vinculin $(\mathrm{VIN})$

a model whereby $\mathrm{CR} 1^{\text {long }}$ protein causes more changes to gene expression levels compared to $C R 1^{\text {short }}$.

\section{$C R 1^{\text {long }}$, but not $\mathrm{CR} 1^{\text {short }}$, is predicted to modulate hematopoietic cell quantity and cell infiltration}

To predict the functional consequences of the genes modified in B6.CR2CR1 $1^{\text {long/long }}, \mathrm{B} 6 . C R 2 C R 1^{\text {short/short }}$ and B6.CR2CR $1^{\text {KO.KO }}$ mice compared to B6, 'Disease and Function Analysis' was performed in IPA. This function predicts increases or decreases in downstream biological activities using the direction of change of the genes in each DE gene list. In the spleen, multiple functional terms were predicted to be increased with the DE genes comparing B6.CR2CR1 long/long with B6. These could be generally classified as being related to regulation of hematopoietic cell number and were predicted to be activated (Fig. 7a). Two terms considered significant were 'quantity of erythroid precursor cells' and 'quantity of myeloid cells'. Interestingly, genes associated with these terms were generally downregulated, including Hba-a1 (-39.74 fold), Hba-a2 (- 19.25 fold) and Hbb-bs (- 20.00 fold) which all encode for hemoglobin subunits (Fig. 7b, c). These data suggest that there is an effect of the $C R 1^{\text {long }}$ allele on hematopoietic quantity, possibly specific to red blood cells, in the spleen. These functional consequences were not associated with DE genes when comparing samples from either B6.CR2CR1 $1^{\text {short/short }}$ or B6.CR2CR $1^{K O / K O}$ with B6.

In the brain samples, functional consequences associated with DE genes comparing B6.CR2CR $1^{\text {long/long }}$ with B6 samples included 'cellular infiltration by leukocytes' and 'infiltration by neutrophils' $(p<0.05$, Fig. $7 d)$. DE genes associated with these terms were generally upregulated including Hyal1 (14.78 fold), Tlr9 (3.44 fold) and Cd276 (4.59 fold) (Fig. 7e,f). HYAL1, a lysosomal hyaluronidase that degrades hyaluronan (a major constituent 
A

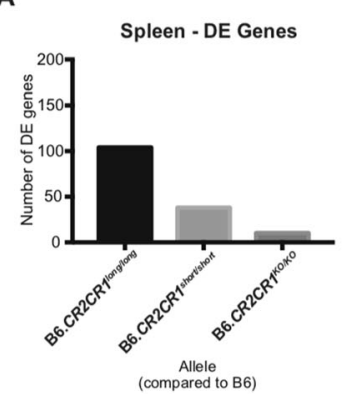

D

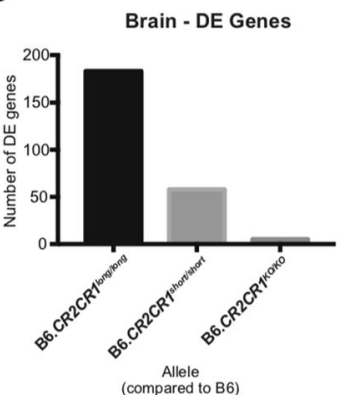

B

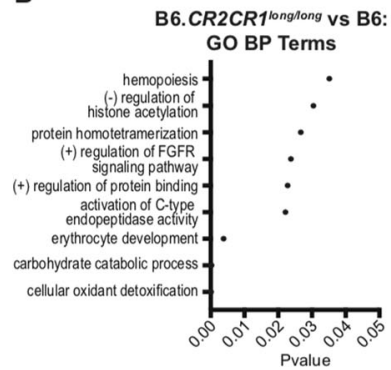

E

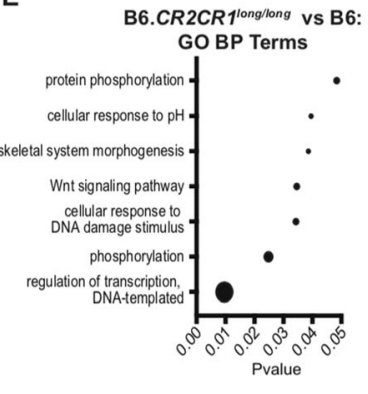

C

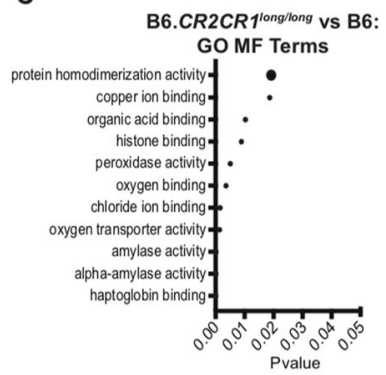

$\mathbf{F}$

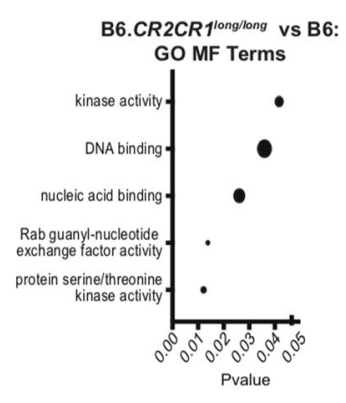

Fig. 6 Transcriptional Profiling of the Spleen and Brain. a Number of differentially expressed (DE) genes $(p<0.05)$ in the spleen for i) B6.CR2CR1 long/long compared to B6, ii) B6.CR2CR1 short/short compared to B6, and iii) B6.CR2CR1 ${ }^{K O / K O}$ compared to B6. b Biological Process (BP) GO terms associated with the 104 DE genes between B6.CR2CR 1 long/long compared to B6 in the spleen. c Molecular Function (MF) GO terms associated with the $104 \mathrm{DE}$ genes between CR2CR long/long compared to B6. $\mathbf{d}$ Number of DE genes between each previous comparison in the brain. e Biological Process (BP) GO terms associated with the 183 DE genes between CR2CR1/ong/long compared to B6. $\mathbf{f}$ Molecular Function (MF) GO terms associated with the 183 DE genes between B6.CR2CR long/long compared to B6. Dot size correlates to number of genes in the pathway associated with each term (see Table S7)

of extracellular matrix), has been shown to be involved in cell proliferation, migration and differentiation [1]. TLR9, a toll-like receptor, plays a critical role in pathogen recognition and activation of innate immunity [11, 67]. CD276, also known as B7-H3, a member of the immunoglobulin superfamily, plays a role in $\mathrm{T}$ cellmediated immune responses $[10,15]$. Collectively, these data predict $C R 1^{\text {long }}$ and $C R 1^{\text {short }}$ in the brain will differentially modulate immune-like cells such as resident microglia or the infiltration and functioning of peripherally derived immune cells - functional differences that may alter risk for diseases such as Alzheimer's disease.

\section{Discussion}

Here, we present a new mouse model expressing the human proteins CR1 and CR2 that will be of value to study of an array of human diseases including Alzheimer's disease $[3,8,9,12,27,34,36,41,72]$, Systemic Lupus Erythematosus $[5,13,29,35,37,48,52,53,60,65,75,78$, 82] and infections such as malaria [4, 37, 71, 83]. We show that the humanized B6.CR2CR1 strain expresses $C R 2$ in place of mouse $\mathrm{Cr} 2$ and is capable of expressing two different isoforms of human CR1 - a long form (2494 amino acids) and a short form (2044 amino acids, lacking one long homologous repeat).
CR1 and CR2 are important regulators of the complement cascade but their specific roles in human diseases have been difficult to study in mouse models due to species differences between humans and mice (Fig. 1) [18, 38, 44, 45, 47, 55, 57-59, 81].

The B6.CR2CR1 mouse model leaves the mouse Crry gene intact. Interestingly, while the murine $C D 21 / \mathrm{Cr} 2$ gene undergoes alternative splicing to encode the two complement receptors, CR1 and CR2; the additional Nterminal domains in CR1 represent duplications of sequences derived from Crry [33]. In primates, the CR2 gene has lost the ability to encode CR1. The human CR1 gene derives from the sub-primate Crry gene through amplification/duplication events; Crry was effectively sacrificed in primates as a consequence. It will be interesting to determine the functional relationship and any interactions between Crry and human forms of CR1 and CR2 in this model.

We anticipate this mouse model will provide an important resource for elucidating the functions of CR1 and CR2 in human diseases - however further work is required to assess its full potential. First, it will be necessary to validate that human forms of CR1 and CR2 regulate the mouse complement system in a similar fashion to those seen in human studies. To do this, both CR2 


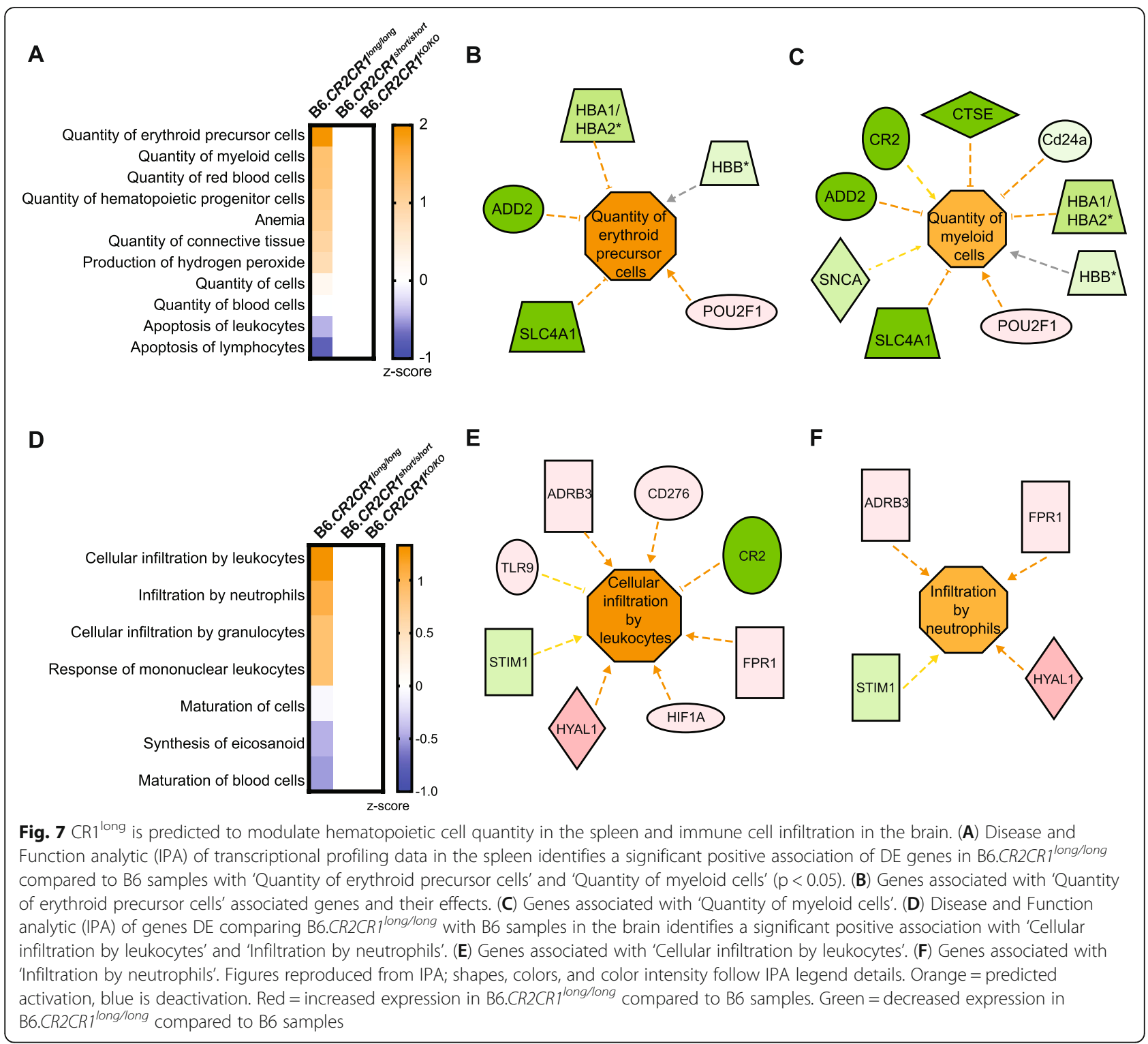

and CR1 (long and short forms) will need to be tested for their ability to bind mouse C3b, C4b and C1q, three central components of the cascade. Second, creating new antibodies that specifically recognize the human isoforms of CR1 expressed in this mouse is required to confirm tissue and cellular distribution patterns in health and disease. Commonly used mouse anti-human CR1 monoclonal antibodies were tested but were unsatisfactory in the B6.CR2CR1 mouse. Some previous studies show available anti-CR1 and anti-CR2 antibodies are inconsistent between assays and tissues samples [26]. Testing existing and new antibodies for human CR1 and CR2 in the B6.CR2CR1 strain as well as in strains deficient in mouse $\mathrm{CR} 2$ protein $\left(\mathrm{B} 6 . \mathrm{Cr} 2^{\mathrm{KO}}\right.$ ) and mouse CRRY protein (B6.Crry ${ }^{K O}$ ) will eliminate the antibody specificity issue and potential for cross-reactivity due to similarities between these homologous genes. Establishing the gene expression patterns of human CR2 and CR1 in specific cell types, particularly in the bone marrow, blood, spleen and blood, will be necessary. Human CR1 is broadly expressed, albeit in varying quantities, on the plasma membranes of blood derived cells, including erythrocytes, eosinophil, monocytes/macrophages, Blymphocytes, dendritic cells and a sub-set of CD4+ Tcells $[17,24,50,51,56,61,62,77]$, on endothelia and numerous cell types in tissues. Erythrocyte CR1 plays an integral role in the clearance of soluble immune complexes, transporting them to macrophages in the spleen and Kupffer cells in the liver $[14,16]$, allowing for these cells to engulf and eliminate immune complexes [69, 74]. The levels of CR1 expression on erythrocytes can differ due to a HindIII restriction fragment length 
polymorphism, which corresponds to a SNP in intron 27 of the CR1 gene [79]. Interestingly, CR1 transcript and protein levels were greater in spleens of mice expressing $\mathrm{CR} 1^{\text {short }}$ compared to $\mathrm{CR} 1^{\text {long }}$ (Figs. 4, 5). This may indicate reduced expression of CR1 ${ }^{\text {long }}$ compared to CR1 $1^{\text {short }}$ per cell and/or differences in the numbers of CR1+ cells in the spleen. Differences in cell number may indicate general baseline differences in hematopoietic cell numbers, or differences in the numbers of CR1+ cells being trafficked from the bone marrow and blood to the spleen. Differences in protein expression may also reflect efficiency of presentation of the different isoforms of CR1 protein at the cell membrane. However, transcript analysis indicated a similar reduction in expression levels of $C R 1^{\text {long }}$ compare to $C R 1^{\text {short }}$. While the functional significance of these differences remains to be elucidated, the B6.CR2CR1 mouse model provides an ideal platform to determine the mechanisms by which the CR1 $1^{\text {long }}$ and $\mathrm{CR} 1^{\text {short }}$ isoforms impact health, the aging process and disease.

The B6.CR2CR1 mouse model also provides an important platform for studying the function of single nucleotide polymorphisms (SNPs) that have been shown to modify CR1 and CR2 function and increase risk for human disease. Several exonic SNPs have been suggested to influence the stability of CR1 on erythrocytes, and thus mediate the high and low levels of expression [83]. While this variation is seen on erythrocytes, leukocyte expression does not show the same variability [78]. Given the current focus on developing treatments for Alzheimer's disease, we expect the B6.CR2CR1 model to be a key resource to advance our understanding of how CR1 risk alleles contribute to disease susceptibility. In 2009, a genome-wide association (GWA) study identified $C R 1$ as a potential risk factor for Alzheimer's disease [41]. This association was corroborated in 2010 [9], 2012 $[8,27,36]$ and 2013 [72]. The exact nature of the association of CR1 with Alzheimer's disease is not well understood. One study [27] proposed the risk for Alzheimer's disease is most likely associated with the B allele of CR1 (CR1-B, equivalent to $C R 1^{\text {long }}$ in this study), with one copy of CR1-B carrying a 1.8x higher risk of disease over the CR1-A/A allele (equivalent to $C R 1^{\text {short }}$ in this study) and a faster rate of cognitive decline. These observations make determining the effects of $C R 1$ variants specifically on brain health of key importance to fully elucidate its role in Alzheimer's disease. Differences in neuronal morphology and distribution between CR1-A/A and CR1-A/B carriers were also reported, the former having a more filiform neuronal structure with CR1 expression that associated with the endoplasmic reticulum, whereas the latter had a more vesicular-like pattern of CR1 expression associating with lysosomes; reduced expression levels of CR1-B in comparison to that of CR1-A were also seen. Another study [36] identified specific CR1 SNPs (rs6656401 and rs4844609) that influenced rate of cognitive decline in Alzheimer's disease in combination with $A P O E$ status. The latter SNP is associated with a single amino acid change in the $\mathrm{C} 1 \mathrm{q}$ binding region of CR1; patients carrying both APOE4 and rs4844609 showed a faster decline in episodic memory. While the functional implications of this coding SNP is yet to be determined, it may impact clearance of $A \beta$ through interfering with $\mathrm{C} 1 \mathrm{q}$ binding [27]. Young adults who carry the CR1 SNP rs6656401 had reduced grey matter volume in the entorhinal cortex [7], an area associated with atrophy in AD patients [6,31]. Biffi et al. [3] also saw drastic differences in entorhinal cortical volume in $\mathrm{AD}$ and $\mathrm{MCI}$ patients depending on their CR1 genotype. Precise gene editing in B6.CR1CR2 mice by methods such as CRISPR/CAS9 allows for the first time these putative risk SNPs to be studied in the context of the different $C R 1$ isoforms.

Analysis of the transcriptional profiling data for the brain suggests that the CR1 isoforms differentially affect immune cell infiltration or immune cell activation, processes that have been shown to be important in disease susceptibility, onset and progression. Critically, the long form of CR1, CR1-B, the reported risk allele for Alzheimer's disease, was associated with a DE gene signature indicating upregulation of pathways labelled 'cellular infiltration by leukocytes' and 'infiltration by neutrophils'; we thus speculate that the association of CR1 $1^{\text {long }}$ with $\mathrm{AD}$ might be explained at least in part, by altered immune cell infiltration into the brain. Interestingly, gene expression profiles of brain and spleen from mice expressing only human CR2 (KO for CR1) appeared very similar to B6 (Fig. 6). These data suggest that in the tissues (brain and spleen) and at the ages (approximately 3 mos) studied, the additional CR2 protein isoform encoded by the mouse $\mathrm{Cr} 2$ gene did not significantly affect gene expression profiles. Therefore, the presence of the additional $\mathrm{Cr} 2$ variant in the mouse genome may be more important during times of stress, during aging or in disease contexts. Further studies in aging mice and incorporating Alzheimer's disease pathologies (such as amyloid and TAU) are required to further corroborate all of the predictions from our transcriptional profiling data.

\section{Conclusion}

The ability to more precisely study $C R 1$ and $C R 2$ in a model system such as the mouse will facilitate our understanding of the role that these receptors, and the complement cascade more generally, play in a wide variety of diseases that show a strong immune component. A more complete understanding of the complement cascade, and its regulators, will lead to more targeted and 
personalized therapeutics for common diseases such as $\mathrm{AD}$ and lupus.

\section{Materials and methods Mouse husbandry}

All mice were maintained on a 12/12 h light/dark cycle. Mice were housed in 6-in. duplex wean cages with pine shavings, group-housed dependent on sex at wean, and maintained on LabDiet ${ }^{\bullet} 5$ K67. The Institutional Animal Care and Use Committee (IACUC) at The Jackson Laboratory (JAX) approved all mice used in this study. Daily monitoring of mice via routine health care checks was carried out to determine general wellbeing, with any mice considered to be unhealthy being euthanized with IACUC approved $\mathrm{CO}_{2}$ euthanasia methods.

\section{Humanizing complement receptors CR1 and CR2}

The B6.CR2CR1 mouse model was created by Genetic Engineering Technologies at JAX via vector targeted embryonic stem (ES) cells. Due to the size, a multi-staged approach was used to create the targeting construct. Regions were designed in silico to encompass the human mRNA transcripts of $C R 2$ and $C R 1$ along with their corresponding human intergenic region (HIR). In parallel to this design a retrieval vector for mouse $\mathrm{Cr} 2$ was utilized, targeted with a Spectinomycin (Spec) cassette, producing a vector with the $5^{\prime}$ and $3^{\prime}$ flanking regions of mouse $\mathrm{Cr} 2(\mathrm{mCr} 2)$. To ensure the integrity of the human genes, they were assembled in a linear manner. The human $\mathrm{Cr} 2$ mini gene was excised from its vector and incorporated within the HIR gap repair vector. This was then targeted to the $\mathrm{mCr} 2 / \mathrm{Spec}$ vector. The $C R 1$ mini genecontaining vector was then targeted using Apal and AvrII restriction enzymes, excising the fragment for integration into the multigene vector. Finally, this multigene vector was targeted with a Neomycin (Neo) cassette at synthetic intron 19 in the human CR2 mini gene. Once the vector was confirmed, C57BL/6 J (B6, Jax \#664) ES cells were targeted, with incorporation occurring at the genomic locus for $\mathrm{mCr} 2$. ES cells were transferred to a blastocyst from a $\mathrm{B} 6(\mathrm{Cg})-\mathrm{Ty} r \mathrm{r}-2 \mathrm{~J} / \mathrm{J}\left(\mathrm{B6}^{\mathrm{Tyr}}\right.$, Jax \#58) and implanted into pseudo-pregnant females. Litters contained a variety of chimeric pups with differing degrees of penetrance.

Chimeric mice from two targeted B6 ES cell lines, $5 \mathrm{H} 4$ and $5 \mathrm{E} 2$, were bred to $\mathrm{B}^{\mathrm{Tyr}}$ mice (Fig. 2). From these, black pups were selected for further breeding as a consequence of B6 ES cells being targeted initially. Mice determined positive through genotyping for the CR2CR1 construct were then bred to B6 to confirm germline transmission (Fig. 2). After germline transmission was confirmed, male mice from each line were sent for sperm cryopreservation, with the Neomycin (Neo) cassette intact, and are available upon request. Mice from the $5 \mathrm{H} 4$ line were used throughout this study.

\section{Developing the $C R 1$ allelic series}

The initial stage of developing the allelic series was to remove the Neo cassette within intron 19 of CR2. To achieve this, mice derived from the $5 \mathrm{H} 4 \mathrm{ES}$ cell line were bred to B6.129S4-Gt(ROSA)26Sortm3(phiC31*)Sor/J (B6.ROSA-Phi, Jax \#7743) mice, to target the attB-attP region surrounding Neo (Fig. 2). Mice negative for Neo were intercrossed to establish B6.CR2CR $1^{\text {long } / \text { long }}$ strain (Figs. 1 and 2). For $C R 1^{\text {short }}$, B6.CR2CR1 $1^{\text {long/+ }}$ mice were crossed to B6.129S4-Gt(ROSA)26Sortm1(FLP1)Dym/ RainJ (B6.ROSA-Flp, Jax \#9086) mice. The Flp recombinase is ubiquitously expressed and targets the removal of LHR1' (Fig. 1) encoded by exons 13-20 (via the flanking FRT sites in synthetic introns 12 and 20; Fig. 2). Mice carrying $C R 1^{\text {short }}\left(\mathrm{B} 6 . \mathrm{CR} 2 \mathrm{CR} 1^{\text {short/+ }}\right)$ were intercrossed to establish the B6.CR2CR $1^{\text {short/short }}$ strain (Figs. 1 and 2). Finally, for $C R 1^{K O}, B 6 . C R 2 C R 1^{\text {long/+ }}$ mice were crossed to B6.Cg- $T g($ Sox2-cre)1Amc/J (Sox2-cre Jax \#8454). In this strain, Cre recombinase is ubiquitously expressed and excises the targeted region using the LoxP sites, located within introns 3 and 20, to create a null allele (knockout, KO). Female B6.Sox2-cre mice were bred to male B6.CR2CR1 $1^{\text {long/+ }}$ mice, as Cre recombinase is active without necessarily needing to be inherited. Mice carrying $C R 1^{K O}$ (B6.CR2CR1 ${ }^{K O /+}$ ) mice were intercrossed to establish the B6.CR2CR1 ${ }^{K O / K O}$ strain (Figs. 1 and 2).

\section{Genotyping}

PCR assays for genotyping were as follows:

For mouse $\mathrm{Cr} 2$ or human CR2 (Fig. 3): Common primer forward primer: $5^{\prime}$ - TCTTCCTCTCCTTGCT ACAGG - 3' C Cr2 Reverse: 5' - AGAAGAGGTGGG GACGTTCT - 3' and CR2 Reverse: 5' - TACCAACA GCAATGGGGGTA - 3' with the $\mathrm{mCr} 2$ product size at $300 \mathrm{bp}$ and the $\mathrm{hCR} 2$ product size at $198 \mathrm{bp}$ with an annealing temperature of $60^{\circ} \mathrm{C}$.

For the HIR Forward 5' - TCACTCACCTCGAGCC ATCT - 3' and Reverse 5' - TCAGCAGGTCTTGGCT TCAG - 3' with a product size of $291 \mathrm{bp}$ at an annealing temperature of $59.3^{\circ} \mathrm{C}$.

For $C R 1^{\text {long }}$ (Fig. 3): Forward 5' - GTACTACGGG AGGCCATTCT - 3' and Reverse $5^{\prime}$ - TGGCTTGG GGTACGCTC - 3' with a product size of $708 \mathrm{bp}$ at an annealing temperature of $58.1^{\circ} \mathrm{C}$.

For $C R 1^{\mathrm{KO}}$ (Fig. 3): Forward 5' - TCTTGTACTACAGG GCACCG - 3' and Reverse 5' - ACCTCTAGGATTAA ACGGTGGGG - 3' with a product size of $150 \mathrm{bp}$ if cre recombination has not occurred, with an annealing temp $57.5^{\circ} \mathrm{C}$. The absence of a band, with a CR1 positive genotype, indicates the removal of exons 4-20. 
For $C R 1^{\text {short }}$ (Fig. 3), forward primer from the $\mathrm{KO}$ allele with the Reverse primer $5^{\prime}$ - CGATCATGGC TCACTGCGAA-3'. A product size of $251 \mathrm{bp}$ is expected if Flp recombination had not occurred. The absence of a band in a combination with a CR1 positive genotype, indicated Flp recombination. The annealing temperature for this reaction was $57.8^{\circ} \mathrm{C}$.

For Crry: Forward 5'- TTGCTAATTGGTAGTGAG GAAAGG - 3' and Reverse 5' - TAAGTTGTTGTGAG GCTTGGGT $-3^{\prime}$ with a product size of $190 \mathrm{bp}$ and an annealing temperature of $55.4^{\circ} \mathrm{C}$.

\section{Cohort generation}

Homozygous mice of the three genotypes CR2CR1 $1^{\text {long/- }}$ long, $C R 2 C R 1^{\text {short/short }}, \mathrm{CR} 2 \mathrm{CR} 1^{\mathrm{KO} / \mathrm{KO}}$ were identified. A separate B6 colony was established for wild-type control samples. Cohorts of at least 4 males and 4 females were used for all assays except for transcriptional profiling where 3 males and 3 females per genotype were assessed. All mice were bled via submandibular bleed and tissue harvested at 3 months of age.

\section{Tissue harvesting and preparation}

Mice were terminally anaesthetized using a Ketamine/ Xylazine $(99 \mathrm{mg} / \mathrm{kg}$ Ketamine, $9 \mathrm{mg} / \mathrm{kg}$ Xylazine) mix. They were transcardially perfused with 1xPBS (phosphate buffered saline $\mathrm{pH}$ 7.4). Spleens and brains were harvested, snap frozen and stored at $-80^{\circ} \mathrm{C}$ for further use. RNA and protein were extracted from snap frozen tissue using Trizol according to manufacturer's instructions. RNA was reconstituted in $\mathrm{dH} 2 \mathrm{O}$ and protein was resuspended in 1:1 1\% SDS/8 M Urea. All RNA and protein samples were stored at $-80{ }^{\circ} \mathrm{C}$ before use. RNA concentrations were determined via Nanodrop and protein concentrations via DC Protein Assay respectively.

\section{CDNA synthesis and reverse transcriptase (RT)-PCR from RNA extracted from spleen}

RNA extracted via Trizol was treated with DNase at $37^{\circ} \mathrm{C}$ for $30 \mathrm{~min}$, the reaction was stopped by placing on ice and 0.5 M EDTA was used to deactivate the DNase. Samples were centrifuged and the supernatant was transferred to a new tube. A lithium chloride:ethanol solution was used to precipitate the RNA overnight at $20^{\circ} \mathrm{C}$. Samples were centrifuged at maximum speed for $20 \mathrm{~min}$ at $+4{ }^{\circ} \mathrm{C}$, the supernatant removed and remaining pellets were washed with $70 \%$ ethanol. RNA was resuspended in $\mathrm{dH}_{2} \mathrm{O}$ and concentrations were read using the Nanodrop. $1 \mu \mathrm{g}$ of RNA was used to synthesize cDNA. Briefly, RNA was combined with random primers, dNTPs, RNase inhibitor, Multiscribe Reverse Transcriptase and made up to volume with $\mathrm{dH}_{2} \mathrm{O}$. The reaction was incubated at $25^{\circ} \mathrm{C}$ for $10 \mathrm{~min}, 37^{\circ} \mathrm{C}$ for $2 \mathrm{~h}$, $85^{\circ} \mathrm{C}$ for $5 \mathrm{~min}$ and $+4{ }^{\circ} \mathrm{C}$. Samples were diluted $1: 4$ and concentrations were read again on the Nanodrop to ensure that no degradation had occurred. Samples were stored at $-20^{\circ} \mathrm{C}$ until required. $100 \mathrm{ng}$ of $\mathrm{cDNA}$ was used to determine expression within the spleen. PCR assays for RT-PCR were as follows:

For CR2 at exon 11: Forward: 5'- TGGGGCAGAA GGACTCCAAT - 3' and Reverse: 5' - GCTCCACCAT GGTCGTCATA - 3' with a product size of $148 \mathrm{bp}$ and an annealing temperature of $60^{\circ} \mathrm{C}$.

For CR1 at exon 2: Forward: 5' - TCCATTTGCC AGGCCTACCA - 3' and Reverse: 5' - TGCACCTGTC CTTAGCACCA $-3^{\prime}$ with a product size of $152 \mathrm{bp}$ and an annealing temperature of $60^{\circ} \mathrm{C}$.

For CR1 spanning exons 4 and 5: Forward: $5^{\prime}$ - TGGT TCCTCGTCTGCCACAT - 3' and Reverse: 5' - AGGA TTGCAGCGGTAGGTCA - 3' with a product size of $178 \mathrm{bp}$ and an annealing temperature $60^{\circ} \mathrm{C}$.

For mCr2: Forward: 5' - TCATGAGGGTACCTGGAG TCA - 3' and Reverse: 5' - AAGAGGAATAGTTGAC CGGTATTT - 3' with a product size of $244 \mathrm{bp}$ and an annealing temperature of $60^{\circ} \mathrm{C}$.

For Crry: Forward: 5' - GGAGGAGTCAAGCTAGAA GTTT - 3' and Reverse: 5' - GTGTTGCAGCGGTAGG TAAC $-3^{\prime}$ with a product size of $521 \mathrm{bp}$ and an annealing temperature of $55.3^{\circ} \mathrm{C}$.

\section{Western blotting}

To determine protein presence and size difference between the CR $1^{\text {long }}$ and $\mathrm{CR} 1^{\text {short }}, 6 \%$ SDS PAGE gels were hand cast. Protein was diluted to $80 \mu \mathrm{g}$ of total protein with 2x Laemmli buffer (BioRad). Samples were denatured at $95^{\circ} \mathrm{C}$ for $5 \mathrm{~min}$ and loaded onto the gel. Gels were run for $1 \mathrm{~h}$ at $150 \mathrm{~V}$ and transferred to nitrocellulose membrane via the iBlot for $13 \mathrm{mins}$. Blots were incubated at room temperature for $1 \mathrm{~h}(\mathrm{hr})$ with blocking solution (5\% skimmed milk powder block in 0.1\% PBSTween), washed with $0.1 \%$ PBS-Tween for three $15 \mathrm{~min}$ incubations and then incubated with rabbit-anti-human CR1 (also known as CD35; Abcam \#ab126737, 1:100) for $48 \mathrm{~h}$ in $0.1 \%$ PBS-Tween on an orbital shaker at $+4{ }^{\circ} \mathrm{C}$. Blots were washed three times in 0.1\% PBS-Tween and incubated with the appropriate secondary (Anti-Rabbit IgG HRP 1: 50,000$)$ for $1.5 \mathrm{~h}$ at RT. Blots were then washed an additional three times and detection was carried out using ECL detection regents (GE Healthcare). When required, blots were stripped by treatment with $0.25 \%$ sodium azide for $2 \mathrm{~h}$ at $\mathrm{RT}$ and washed thoroughly in $0.1 \%$ PBS-Tween. Blots were re-blocked and re-probed with mouse anti-CD21 (anti-human CR2; Abcam \#ab54253, 1:100) in 0.1\% PBS-Tween overnight at $+4{ }^{\circ} \mathrm{C}$. Blots were washed and incubated in the appropriate secondary antibody (Anti-Mouse IgG HRP 1:40, 000), washed and detected. Finally, blots were treated with $0.25 \%$ sodium azide and probed with a loading 
control, anti-Vinculin $(1: 10,000)$ in $0.1 \%$ PBS-Tween overnight at $+4{ }^{\circ} \mathrm{C}$, washed three times, incubated with the appropriate secondary antibody (Anti-Rabbit HRP 1: $50,000)$ for $1 \mathrm{~h}$ at RT, washed and detected.

\section{Transcriptional profiling} RNA isolation, library preparation and sequencing

RNA was isolated from tissue using the MagMAX mirVana Total RNA Isolation Kit (ThermoFisher) and the KingFisher Flex purification system (ThermoFisher). Tissues were lysed and homogenized in TRIzol Reagent (ThermoFisher). After the addition of chloroform, the RNA-containing aqueous layer was removed for RNA isolation according to the manufacturer's protocol, beginning with the RNA bead binding step. RNA concentration and quality were assessed using the Nanodrop (Thermo Scientific) and the RNA Total RNA Nano assay (Agilent Technologies). Libraries were prepared by the Genome Technologies core facility at The Jackson Laboratory using the KAPA mRNA HyperPrep Kit (KAPA Biosystems), according to the manufacturer's instructions. Briefly, the protocol entails isolation of polyAcontaining mRNA using oligo-dT magnetic beads, RNA fragmentation, first and second strand cDNA synthesis, ligation of Illumina-specific adapters containing a unique barcode sequence for each library, and PCR amplification. Libraries were checked for quality and concentration using the D5000 assay on the TapeStation (Agilent Technologies) and quantitative PCR (KAPA Biosystems), performed according to the manufacturers' instructions. Libraries were pooled and sequenced by the Genome Technologies core facility at JAX, generating $100 \mathrm{bp}$ paired-end reads on the HiSeq 4000 (Illumina) using HiSeq 3000/4000 SBS Kit reagents (Illumina).

\section{Sequence Alignment \& Statistical Analysis Methods}

FASTQ files were trimmed using Trimmomatic v0.33 which removed adapters and sequences with more than 2 mismatches, a quality score $<30$ for PE palindrome reads, or a quality score of $<10$ for a match between any adapter sequence against a read. A sliding window of 4 bases was used with a required (average) minimum quality score threshold of 15 . The leading and trailing minimum quality score thresholds were set to 3 to keep a base. Reads had to be 36 bases or greater in length. Sequence alignment was completed using the Mus musculus Ensembl v82 reference genome in addition to three custom references based on the strain. Samples from both brain and spleen tissue were edited to include human $C R 2$ and one (or none) of three human sequences: $C R 1^{\text {long }}, C R 1^{\text {short }}$, or $C R 1 \mathrm{KO}$. Each of the three human sequences was appended to the Mus musculus reference genome individually; thus, three additional reference genomes were created to quantitate gene and isoform expression levels using RSEM v1.2.19. B6 samples were evaluated with the base Mus musculus reference genome. RSEM leveraged Bowtie2 alignment with strandspecific and paired-end parameters. The resulting gene/ transcript (feature) count data were processed using edgeR v3.14.0 ( $\mathrm{R}$ v3.3.1). For each of the four datasets (brain and spleen, gene and transcript), feature differential expression was evaluated in three pairwise comparisons per sex: 1.) $C R 1^{\text {long }}$ vs. B6, 2.) $C R 1^{\text {short }}$ vs. B6, and 3.) $C R 1^{K O}$ vs. B6. Any feature that did not have at least 1 read per million for at least 2 samples in either sets of samples evaluated in the pairwise comparison was excluded from the differential expression analysis. The Cox-Reid profile-adjusted likelihood method was used to derive tagwise dispersion estimates based on a trended dispersion estimate. The GLM likelihood ratio test was used to evaluate differential expression in pairwise comparisons between sample groups. The Benjamini and Hochberg's algorithm was used to control the false discovery rate (FDR). Features with an FDR-adjusted $p$-value $<0.05$ were declared statistically significant.

\section{Gene set enrichment}

The Database for Annotation, Visualization and Integrated Discovery (DAVID, v6.8) was used on each significant DE gene list for each pairwise comparison to identify enrichment of Kyoto Encyclopedia of Genes and Genomes (KEGG) pathways and Gene Ontology (GO) terms. Background gene sets were all trimmed normalized gene reads. KEGG pathways and GO terms were considered enriched with a p-value less than 0.05 $(p<0.05)$. Ingenuity Pathway Analysis (IPA) was used for disease and functional analysis.

\section{Supplementary information}

Supplementary information accompanies this paper at https://doi.org/10. 1186/s12863-020-00893-9.

\section{Additional file 1. \\ Additional file 2. \\ Additional file 3. \\ Additional file 4. \\ Additional file 5. \\ Additional file 6. \\ Additional file 7. \\ Additional file 8 . \\ Additional file 9.}

\section{Acknowledgements}

The authors would like to thank The Jackson Laboratory Genetic Engineering Technologies for support in creating the B6.CR2CR1 mouse model. They also thank Dr. Vivek Philip for assistance with analysis of transcriptional profiling data. 


\section{Authors' contributions}

HMJ, BPM and GRH conceived the study. HMJ performed experiments. ROR developed mouse cohorts. TMS and KEF performed analysis of transcriptional profiling data. DF validated and provided antibodies. HMJ, KEF, GRH and BPM wrote the manuscript. All authors approved the submission of the manuscript.

\section{Funding}

This work was funded in part by NS091571 (GRH), AG051496 (GRH) and AG054345 (GRH). BMP receives funding from the Medical Research Council, the Alzheimer's Society and Alzheimer's Research UK via the UK Dementia Research Institute.

\section{Availability of data and materials}

The B6.CR2CR1 mouse strain is available on request to gareth.howell@jax.org as well as from The Jackson Laboratory (https://www.jax.org/strain/027713) or MODEL-AD (http://model-ad.org). All RNA-seq data is being made available in GeoArchive (ID pending - data will be provided prior to acceptance of this manuscript and this statement will be amended accordingly).

\section{Ethics approval and consent to participate}

No human subjects or data was used in this study. All experiments involving mice were approved by the Animal Care and Use Committee at The Jackson Laboratory in accordance with guidelines set out in The Eighth Edition of the Guide for the Care and Use of Laboratory Animals. All euthanasia methods were approved by the American Veterinary Medical Association.

\section{Consent for publication}

Not applicable.

\section{Competing interests}

No financial or competing interests declared.

\section{Author details}

${ }^{1}$ The Jackson Laboratory, 600 Main Street, Bar Harbor, ME, USA. ${ }^{2}$ Dementia Research Institute Cardiff and Systems Immunity Research Institute, School of Medicine, Cardiff University, Cardiff, Wales, UK. ${ }^{3}$ Graduate School of Biomedical Sciences, Tufts University School of Medicine, Boston, MA, USA. ${ }^{4}$ Graduate School of Biomedical Sciences and Engineering, University of Maine, Orono, ME, USA.

\section{Received: 21 April 2020 Accepted: 21 July 2020}

Published online: 09 September 2020

\section{References}

1. Bharadwaj AG, Rector K, Simpson MA. Inducible Hyaluronan production reveals differential effects on prostate tumor cell growth and tumor angiogenesis. J Biol Chem. 2007;282:20561-72.

2. Biffi A. Genetic variation at CR1 increases risk of cerebral amyloid angiopathy. Neurology. 2012;78(5):334-41.

3. Biffi A, Anderson CD, Desikan RS, Sabuncu M, Cortellini L, Schmansky N, Salat D, Rosand J. Genetic variation and neuroimaging measures in Alzheimer disease. Arch Neurol. 2010;67:677-85.

4. Birmingham DJ, Chen W, Liang G, Schmitt HC, Gavit K, Nagaraja HN. A CR1 polymorphism associated with constitutive erythrocyte CR1 levels affects binding to C4b but not C3b. Immunology. 2003;108:531-8.

5. Birmingham DJ, Gavit KF, McCarty SM, Yu CY, Rovin BH, Nagaraja HN, Hebert LA. Consumption of erythrocyte CR1 (CD35) is associated with protection against systemic lupus erythematosus renal flare. Clin Exp Immunol. 2006;143:274-80.

6. Braak H, Braak E. Neuropathological staging of Alzheimer-related changes. Acta Neuropathol. 1991;82:239-59.

7. Bralten J, Franke B, Arias-Vásquez A, Heister A, Brunner HG, Fernández G, Rijpkema M. CR1 genotype is associated with entorhinal cortex volume in young healthy adults. Neurobiol. Aging. 2011;32:2106.e7-11.

8. Brouwers N, Van Cauwenberghe C, Engelborghs S, Lambert J-C, Bettens K, Le Bastard N, Pasquier F, Montoya AG, Peeters K, Mattheijssens M, et al. Alzheimer risk associated with a copy number variation in the complement receptor 1 increasing C3b/C4b binding sites. Mol Psychiatry. 2012;17:223-33.

9. Carrasquillo MM, Belbin O, Hunter TA, Ma L, Bisceglio GD, Zou F, Crook JE, Pankratz VS, Dickson DW, Graff-Radford NR, et al. Replication of CLU,
CR1, and PICALM associations with alzheimer disease. Arch Neurol. 2010;67:961-4

10. Chapoval Al, Ni J, Lau JS, Wilcox RA, Flies DB, Liu D, Dong H, Sica GL, Zhu G, Tamada K, et al. B7-H3: a costimulatory molecule for T cell activation and IFN- $\gamma$ production. Nat Immunol. 2001;2:269-74.

11. Christensen SR, Shupe J, Nickerson K, Kashgarian M, Flavell RA, Shlomchik MJ. Toll-like receptor 7 and TLR9 dictate autoantibody specificity and have opposing inflammatory and regulatory roles in a murine model of lupus. Immunity. 2006;25:417-28.

12. Corneveaux JJ, Myers AJ, Allen AN, Pruzin JJ, Ramirez M, Engel A, Nalls MA, Chen K, Lee W, Chewning K, et al. Association of CR1, CLU, and PICALM with Alzheimer's disease in a cohort of clinically characterized and neuropathologically verified individuals. Hum Mol Genet. 2010; 19(16):3295-301.

13. Corvetta A, Pomponio G, Bencivenga R, Luchetti MM, Spycher M, Spaeth PJ, Danieli G. Low number of complement C3b/C4b receptors (CR1) on erythrocytes from patients with essential mixed cryoglobulinemia, systemic lupus erythematosus and rheumatoid arthritis: relationship with disease activity, anticardiolipin antibodies, complement activat. J Rheumatol. 1991; 18:1021-5.

14. Cosio FG, Shen XP, Birmingham DJ, Van Aman M, Hebert LA. Evaluation of the mechanisms responsible for the reduction in erythrocyte complement receptors when immune complexes form in vivo in primates. J Immunol. 1990;145:4198-206.

15. Coyle AJ, Gutierrez-Ramos J-C. The expanding B7 superfamily: increasing complexity in costimulatory signals regulating $\mathrm{T}$ cell function. Nat Immunol. 2001;2:203-9.

16. Craig ML, Bankovich AJ, Taylor RP. Visualization of the transfer reaction: tracking immune complexes from erythrocyte complement receptor 1 to macrophages. Clin Immunol. 2002;105:36-47.

17. Danielsson C, Pascual M, French L, Steiger G, Schifferli JA. Soluble complement receptor type 1 (CD35) is released from leukocytes by surface cleavage. Eur J Immunol. 1994;24:2725-31.

18. Davoust N, Nataf S, Holers VM, Barnum SR. Expression of the murine complement regulatory protein crry by glial cells and neurons. Glia. 1999:27:162-70.

19. Del Rio-Tsonis K, Tsonis PA, Zarkadis IK, Tsagas AG, Lambris JD. Expression of the third component of complement, $\mathrm{C} 3$, in regenerating limb Blastema cells of Urodeles. J Immunol. 1998;161:6819-24.

20. Dykman TR, Cole JL, lida K, Atkinson JP. Polymorphism of human erythrocyte C3b/C4b receptor. Proc Natl Acad Sci. 1983a;80:1698-702.

21. Dykman TR, Cole JL, lida K, Atkinson JP. Structural heterogeneity of the C3b/ C4b receptor ( $\mathrm{Cr}$ 1) on human peripheral blood cells. J Exp Med. 1983b;157: 2160-5.

22. Dykman TR, Hatch JA, Atkinson JP. Polymorphism of the human C3b/C4b receptor. Identification of a third allele and analysis of receptor phenotypes in families and patients with systemic lupus erythematosus. J Exp Med. 1984;159:691-703

23. Dykman TR, Hatch JA, Aqua MS, Atkinson JP. Polymorphism of the C3b/ C4b receptor (CR1): characterization of a fourth allele. J Immunol. 1985; 134:1787-9.

24. Fang Y, Xu C, Fu YX, Holers VM, Molina H. Expression of complement receptors 1 and 2 on follicular dendritic cells is necessary for the generation of a strong antigen-specific lgG response. J Immunol. 1998;160:5273-9.

25. Farries TC, Atkinson JP. Evolution of the complement system. Immunol Today. 1991;12:295-300.

26. Fonseca Ml, Chu S, Pierce AL, Brubaker WD, Hauhart RE, Mastroeni D, Clarke EV, Rogers J, Atkinson JP, Tenner AJ. Analysis of the putative role of CR1 in Alzheimer's disease: genetic association, expression and function. PLoS One. 2016;11:e0149792.

27. Hazrati LN, Van Cauwenberghe C, Brooks PL, Brouwers N, Ghani M, Sato C, Cruts M, Sleegers K, St. George-Hyslop P, Van Broeckhoven C, et al. Genetic association of CR1 with Alzheimer's disease: A tentative disease mechanism. Neurobiol Aging. 2012;33:2949.e5-2949.e12.

28. Holers VM, Chaplin DD, Leykam JF, Gruner BA, Kumar V, Atkinson JP. Human complement C3b/C4b receptor (CR1) mRNA polymorphism that correlates with the CR1 allelic molecular weight polymorphism. Proc Natl Acad Sci U S A. 1987:84:2459-63.

29. Holme E, Fyfe A, Zoma A, Veitch J, Hunter J, Whaley K. Decreased C3b receptors (CR1) on erythrocytes from patients with systemic lupus erythematosus. Clin Exp Immunol. 1986;63:41-8. 
30. Hourcade D, Garcia AD, Post TW, Taillon-Miller P, Holers VM, Wagner LM, Bora NS, Atkinson JP. Analysis of the human regulators of complement activation (RCA) gene cluster with yeast artificial chromosomes (YACS). Genomics. 1992;12:289-300.

31. Hyman BT, Van Hoesen GW, Damasio AR, Barnes CL. Alzheimer's disease: cell-specific pathology isolates the hippocampal formation. Science. 1984; 225:1168-70.

32. lida $K$, Mornaghi $R$, Nussenzweig V. Complement receptor (CR1) deficiency in erythrocytes from patients with systemic lupus erythematosus. J Exp Med. 1982;155:1427-38.

33. Jacobson AC, Weis $\mathrm{JH}$. Comparative functional evolution of human and mouse CR1 and CR2. J Immunol. 2008;181:2953-9.

34. Jun G, Naj AC, Beecham GW, et al. MEta-analysis confirms cr1, clu, and picalm as alzheimer disease risk loci and reveals interactions with apoe genotypes. Arch Neurol. 2010;67:1473-84.

35. Katyal M, Sivasankar B, Ayub S, Das N. Genetic and structural polymorphism of complement receptor 1 in normal Indian subjects. Immunol Lett. 2003;89:93-8.

36. Keenan BT, Shulman JM, Chibnik LB, Raj T, Tran D, Sabuncu MR, Allen AN, Corneveaux JJ, Hardy JA, Huentelman MJ, et al. A coding variant in CR1 interacts with APOE- $\varepsilon 4$ to influence cognitive decline. Hum Mol Genet. 2012;21:2377-88

37. Khera R, Das N. Complement receptor 1: disease associations and therapeutic implications. Mol Immunol. 2009;46:761-72.

38. Killick R, Hughes TR, Morgan BP, Lovestone S. Deletion of Crry, the murine ortholog of the sporadic Alzheimer's disease risk gene CR1, impacts tau phosphorylation and brain CFH. Neurosci Lett. 2013;533:96-9.

39. Klickstein LB, Bartow TJ, Miletic V, Rabson LD, Smith JA, Fearon DT. Identification of distinct C3b and C4b recognition sites in the human C3b/C4b receptor (CR1, CD35) by deletion mutagenesis. J Exp Med. 1988;168:1699-717.

40. Krych-Goldberg M, Hauhart RE, Subramanian VB, Yurcisin BM, Crimmins DL, Hourcade DE, Atkinson JP. Decay accelerating activity of complement receptor type 1 (CD35): Two active sites are required for dissociating c5 convertases. J Biol Chem. 1999;274:31160-8.

41. Lambert J-C, Heath S, Even G, Campion D, Sleegers K, Hiltunen M, Combarros O, Zelenika D, Bullido MJ, Tavernier B, et al. Genome-wide association study identifies variants at CLU and CR1 associated with Alzheimer's disease. Nat Genet. 2009;41:1094-9.

42. Lublin DM, Lemons RS, Le Beau MM, Holers VM, Tykocinski ML, Medof ME, Atkinson JP. The gene encoding decay-accelerating factor (DAF) is located in the complement-regulatory locus on the long arm of chromosome 1. J Exp Med. 1987;165:1731-6.

43. Lublin DM, Liszewski MK, Post TW, Arce MA, Le Beau MM, Rebentisch MB, Lemons LS, Seya T, Atkinson JP. Molecular cloning and chromosomal localization of human membrane cofactor protein (MCP). Evidence for inclusion in the multigene family of complement-regulatory proteins. J Exp Med. 1988;168:181-94.

44. Maier M, Peng Y, Jiang L, Seabrook TJ, Carroll MC, Lemere CA. Complement C3 deficiency leads to accelerated amyloid beta plaque deposition and neurodegeneration and modulation of the microglia/macrophage phenotype in amyloid precursor protein transgenic mice. J Neurosci. 2008;28:6333-41.

45. Manickam B, Jha P, Hepburn NJ, Morgan BP, Harris CL, Bora PS, Bora NS. Suppression of complement activation by recombinant Crry inhibits experimental autoimmune anterior uveitis (EAAU). Mol Immunol. 2010;48:231-9.

46. Mao DL, Wu XB, Deppong C, Friend LD, Dolecki G, Nelson DM, Molina H. Negligible role of antibodies and C5 in pregnancy loss associated exclusively with C3-dependent mechanisms through complement alternative pathway. Immunity. 2003;19:813-22.

47. Marchbank KJ, Kulik L, Gipson MG, Morgan BP, Holers VM. Expression of human complement receptor type 2 (CD21) in mice during early B cell development results in a reduction in mature $B$ cells and Hypogammaglobulinemia. J Immunol. 2002;169:3526 LP-3535.

48. Marquart HV, Svendsen A, Rasmussen JM, Nielsen CH, Junker P, Svehag SE, Leslie RG. Complement receptor expression and activation of the complement cascade on B lymphocytes from patients with systemic lupus erythematosus (SLE). Clin Exp Immunol. 1995;101:60-5.

49. Mastellos D, Lambris JD. Complement: more than a "guard" against invading pathogens? Trends Immunol. 2002;23:485-91.

50. Merle NS, Church SE, Fremeaux-Bacchi V, Roumenina LT. Complement system part I - molecular mechanisms of activation and regulation. Front Immunol. 2015a;6:1-30.
51. Merle NS, Noe R, Halbwachs-Mecarelli L, Fremeaux-Bacchi V, Roumenina LT. Complement system part II: role in immunity. Front Immunol. 2015b;6:1-26.

52. Miyakawa Y, Yamada A, Kosaka K, Tsuda F, Kosugi E, Mayumi M. Defective immune-adherence $(\mathrm{c} 3 \mathrm{~b})$ receptor on erythrocytes from patients with systemic lupus erythematosus. Lancet. 1981;318:493-7.

53. Moulds JM, Reveille JD, Arnett FC. Structural polymorphisms of complement receptor 1 (CR1) in systemic lupus erythematosus (SLE) patients and normal controls of three ethnic groups. Clin Exp Immunol. 1996;105:302-5.

54. Nonaka M. Evolution of the complement system. Curr Opin Immunol. 2001;13:69-73.

55. Pappworth IY, Hayes C, Dimmick J, Morgan BP, Holers VM, Marchbank KJ. Mice expressing human CR1/CD35 have an enhanced humoral immune response to T-dependent antigens but fail to correct the effect of premature human CR2 expression. Immunobiology. 2012;217:147-57.

56. Pascual M, Duchosal MA, Steiger G, Giostra E, Pechère A, Paccaud JP, Danielsson C, Schifferli JA. Circulating soluble CR1 (CD35). Serum levels in diseases and evidence for its release by human leukocytes. J Immunol. 1993;151:1702-11.

57. Prodeus AP, Goerg S, Shen LM, Pozdnyakova OO, Chu L, Alicot EM, Goodnow CC, Carroll MC. A critical role for complement in maintenance of self-tolerance. Immunity. 1998;9:721-31.

58. Ramaglia V, Hughes TR, Donev RM, Ruseva MM, Wu X, Huitinga I, Baas F, Neal JW, Morgan BP. C3-dependent mechanism of microglial priming relevant to multiple sclerosis. Proc Natl Acad Sci U S A. 2012;109:965-70.

59. Repik A, Pincus SE, Ghiran I, Nicholson-Weller A, Asher DR, Cerny AM, Casey LS, Jones SM, Jones SN, Mohamed N, et al. A transgenic mouse model for studying the clearance of blood-borne pathogens via human complement receptor 1 (CR1). Clin Exp Immunol. 2005;140:230-40.

60. Richardson B, Scheinbart L, Strahler J, Gross L, Hanash S, Johnson M. Evidence for impaired T cell DNA methylation in systemic lupus erythematosus and rheumatoid arthritis. Arthritis Rheum. 1990;33:1665-73.

61. Rodgaard A, Christensen LD, Thomsen BS, Wiik A, Bendixen G. Complement receptor type 1 (CR1, CD35) expression on peripheral T lymphocytes: both CD4- and CD8-positive cells express CR1. Complement Inflamm. 1991;8:303-9.

62. Rodgaard A, Thomsen BS, Bendixen G, Bendtzen K. Increased expression of complement receptor type 1 (CR1, CD35) on human peripheral blood T lymphocytes after polyclonal activation in vitro. Immunol Res. 1995;14:69-76.

63. Rodriguez de Cordoba S, Rubinstein P. Quantitative variations of the C3b/ C4b receptor (CR1) in human erythrocytes are controlled by genes within the regulator of complement activation (RCA) gene cluster. J Exp Med. 1986;164:1274-83.

64. Rodriguez de Cordoba S, Lublin DM, Rubinstein P, Atkinson JP. Human genes for three complement components that regulate the activation of C3 are tightly linked. J Exp Med. 1985;161:1189-95.

65. Ross GD, Yount WJ, Walport MJ, Winfield JB, Parker CJ, Fuller CR, Taylor RP, Myones BL, Lachmann PJ. Disease-associated loss of erythrocyte complement receptors (CR1, C3b receptors) in patients with systemic lupus erythematosus and other diseases involving autoantibodies and/or complement activation. J Immunol. 1985:135:2005-14.

66. Rutkowski MJ, Sughrue ME, Kane AJ, Ahn BJ, Fang S, Parsa AT. The complement cascade as a mediator of tissue growth and regeneration. Inflamm Res. 2010;59:897-905.

67. Santiago-Raber M-L, Baudino L, Izui S. Emerging roles of TLR7 and TLR9 in murine SLE. J Autoimmun. 2009;33:231-8.

68. Schafer DP, Stevens B. Synapse elimination during development and disease: immune molecules take Centre stage. Biochem Soc Trans. 2010;38: 476-81.

69. Skogh T, Blomhoff R, Eskild W, Berg T. Hepatic uptake of circulating lgG immune complexes. Immunology. 1985;55:585-94.

70. Stevens B, Allen NJ, Vazquez LE, Howell GR, Christopherson KS, Nouri N, Micheva KD, Mehalow AK, Huberman AD, Stafford B, et al. The classical complement cascade mediates CNS synapse elimination. Cell. 2007;131: 1164-78.

71. Thomas BN, Donvito B, Cockburn I, Fandeur T, Rowe JA, Cohen JHM, Moulds JM. A complement receptor-1 polymorphism with high frequency in malaria endemic regions of Asia but not Africa. Genes Immun. 2005;6:31-6.

72. Van Cauwenberghe C, Bettens K, Engelborghs S, Vandenbulcke M, Van Dongen J, Vermeulen S, Vandenberghe R, De Deyn PP, Van Broeckhoven C, 
Sleegers K. Complement receptor 1 coding variant p.Ser1610Thr in Alzheimer's disease and related endophenotypes. Neurobiol Aging. 2013;34: 2235.e1-6.

73. Van Dyne S, Holers VM, Lublin DM, Atkinson JP. The polymorphism of the $\mathrm{C} 3 \mathrm{~b} / \mathrm{C} 4 \mathrm{~b}$ receptor in the normal population and in patients with systemic lupus erythematosus. Clin Exp Immunol. 1987;68:570-9.

74. van Es LA, Daha MR. Factors influencing the endocytosis of immune complexes. Adv Nephrol Necker Hosp. 1984;13:341-67.

75. Walport MJ, Ross GD, Mackworth-Young C, Watson JV, Hogg N, Lachmann PJ. Family studies of erythrocyte complement receptor type 1 levels: reduced levels in patients with SLE are acquired, not inherited. Clin Exp Immunol. 1985;59:547-54.

76. Weis JH, Morton CC, Bruns GA, Weis JJ, Klickstein LB, Wong WW, Fearon DT, A complement receptor locus: genes encoding C3b/C4b receptor and C3d/ Epstein-Barr virus receptor map to 1q32. J Immunol. 1987:138:312-5.

77. Weiss L, Fischer E, Haeffner-Cavaillon N, Jouvin MH, Appay MD, Bariety J, Kazatchkine M. The human C3b receptor (CR1). Adv Nephrol Necker Hosp. 1989;18:249-69

78. Wilson JG, Ratnoff WD, Schur PH, Fearon DT. Decreased expression of the $\mathrm{C} 3 \mathrm{~b} / \mathrm{C} 4 \mathrm{~b}$ receptor (CR1) and the C3d receptor (CR2) on B lymphocytes and of CR1 on neutrophils of patients with systemic lupus erythematosus. Arthritis Rheum. 1986:29:739-47.

79. Wilson JG, Wong WW, Murphy EE 3rd, Schur PH, Fearon DT. Deficiency of the $\mathrm{C} 3 \mathrm{~b} / \mathrm{C} 4 \mathrm{~b}$ receptor (CR1) of erythrocytes in systemic lupus erythematosus: analysis of the stability of the defect and of a restriction fragment length polymorphism of the CR1 gene. J Immunol. 1987;138: 2708-10.

80. Wong WW, Cahill JM, Rosen MD, Kennedy CA, Bonaccio ET, Morris MJ, Wilson JG, Klickstein LB, Fearon DT. Structure of the human CR1 gene. Molecular basis of the structural and quantitative polymorphisms and identification of a new CR1-like allele. J Exp Med. 1989;169:847-63.

81. Wu X, Jiang N, Deppong C, Singh J, Dolecki G, Mao D, Morel L, Molina HD. A role for the $\mathrm{Cr} 2$ gene in modifying autoantibody production in systemic lupus erythematosus. J Immunol. 2002;169:1587-92.

82. Wu H, Boackle SA, Hanvivadhanakul P, Ulgiati D, Grossman JM, Lee Y, Shen $\mathrm{N}$, Abraham $\sqcup$, Mercer TR, Park E, et al. Association of a common complement receptor 2 haplotype with increased risk of systemic lupus erythematosus. Proc Natl Acad Sci. 2007;104:3961-6.

83. Xiang L, Rundles JR, Hamilton DR, Wilson JG. Quantitative alleles of CR1 coding sequence analysis and comparison of haplotypes in two ethnic groups. J Immunol. 1999;163:4939-45.

84. Xu C, Mao D, Holers VM, Palanca B, Cheng AM, Molina H. A critical role for murine complement regulator Crry in Fetomaternal tolerance. Science. 2000:287(80):498 LP-501.

85. Zhang $Y$, Nester CM, Holanda DG, Marsh HC, Hammond RA, Thomas $L$, Meyer NC, Hunsicker LG, Sethi S, Smith RJH. Soluble CR1 therapy improves complement regulation in C3 Glomerulopathy. J Am Soc Nephrol. 2013;24:1820-9.

\section{Publisher's Note}

Springer Nature remains neutral with regard to jurisdictional claims in published maps and institutional affiliations.

Ready to submit your research? Choose BMC and benefit from:

- fast, convenient online submission

- thorough peer review by experienced researchers in your field

- rapid publication on acceptance

- support for research data, including large and complex data types

- gold Open Access which fosters wider collaboration and increased citations

- maximum visibility for your research: over $100 \mathrm{M}$ website views per year

At $\mathrm{BMC}$, research is always in progress.

Learn more biomedcentral.com/submissions 